\title{
Performance Evaluation and Optimal Sizing of Solar Water Pumping System Compared to Convention Diesel of Remote Site in Egypt
}

Marwa M. Ibrahim (D yara_mh2003@yahoo.com )

Mechanical Engineering Department, Engineering Research Division, National Research Centre (NRC) 12622, Egypt

\section{Original Article}

Keywords: Agricultural, Irrigation, Water pumping, Diesel generator, Renewable Energy, Solar photovoltaic Energy, Cost analysis, Simulation, Net present Cost, Cost of Energy

Posted Date: September 22nd, 2020

DOI: https://doi.org/10.21203/rs.3.rs-78887/v1

License: (c) (i) This work is licensed under a Creative Commons Attribution 4.0 International License.

Read Full License 


\title{
Performance Evaluation and Optimal Sizing of Solar Water Pumping System Compared to convention Diesel of Remote Site in Egypt
}

\author{
Marwa M. Ibrahim
}

Mechanical Engineering Department, Engineering Research Division, National Research Centre (NRC) 12622, Egypt

E-mail:Marwa.Ibrahim@med.sci.eg, Mobile: +201116032559

\begin{abstract}
The lack of electricity; high diesel prices affect Community water supply and irrigation pumping requirements and recent environmental issues coupled with diesel engines demand for a feasible alternative power source for irrigation water pumping. Solar power for water pumping is a good option and attractive choice for conventional diesel-based pumping systems. These systems have been introduced for various applications in many remote areas, ranging from grid extension and community water management to irrigation for agriculture and water supplies for livestock. The aim of this study is to evaluate technical, economic and environmental analysis of solar water pumping systems performance and compare them with convention diesel pumping systems to meet water requirements in irrigation, livestock watering, and neighborhood water supply fields. Recognition system design and selecting suitable design parameters is essential in order to achieve consistent and economical performance of any system. In order to design a solar water pumping system, it is necessary to collect information about the system components and local location climate data. Here, the maximum pumping power required of the solar PV water pumping system, which was determined for $121 \mathrm{~m}^{3} / \mathrm{hr}$ supply is $443 \mathrm{~kW}$ peak $(8477$ $\mathrm{kWh} /$ day) of inhabits residential, live stock and crops irrigation of agriculture remote site without grid power located in El Gharaq, Etsa Region, Fayoum City, Egypt. In parallel, a battery bank has been used as a backup during days of autonomy to increase the system stability. The system design investigates: diesel system, off-grid PV/battery system and compares with PV/Grid system extension power grid. The system model approach defines optimum system configurations with minimal cost of the photovoltaic modules, optimum battery bank size, and volume of storage tank. The optimization model takes into account the average monthly solar radiation, the fulfilling of the water required and the amount of autonomous days needed. The proposed sizing methodology is then performed to check the reliability of this proposed optimization method using commercial optimization software of HOMER 3.13.8, with the key parameters of minimum NPC and COE that shows better results using the system method proposed. It also estimates the pumping power capacity using calculations and equations. The results illustrated that the optimal configurations of this proposed system are $2.57 \mathrm{~kW}$ of PV and $2.11 \mathrm{~kW}$ converter of on-grid system while $3.83 \mathrm{~kW} \mathrm{PV}$ and $1.71 \mathrm{~kW}$ converter and 10 units of $12 \mathrm{~V}$ batteries for PV/battery off-grid system and $3.10 \mathrm{~kW}$ PV for diesel system. Also, it was found that the net present cost of solar water pumping system for on-grid mode is equal 3 times of the PV-battery off-grid system and 4 times of convention diesel system net present costs. The cost of energy of solar water pumping system is 0.07 $\$ / \mathrm{kWh}$ for on-grid system while $0.332 \$ / \mathrm{kWh}$ for PV-battery off-grid system and $0.434 \$ / \mathrm{kWh}$ for diesel system. With a unit of $0.05 \mathrm{cent} / \mathrm{m}^{3}$, the system with the specified design pumps an average hourly water volume of about $121.4 \mathrm{~m}^{3}$ over one year. The return on investment is found to be 4-6 years for solar water pumping systems. Moreover, from an environmental point of view, the results showed that $\mathrm{CO}_{2}$ output for the on-grid solar water pumping system during the project's lifetime is 6 times lower than that for the standard diesel system. Through sensitivity analysis; energy costs increase by increasing the water storage tank's maximum capacity. Also, when discount rate is increasing; the NPC and COE are also increasing. The Pumping Power capacity is also estimated for this water pumping system and it is found around $10 \mathrm{HP}$. The results indicate that extension PV on-grid pumping system is the optimum solution for the selected site. Latest Egyptian Photovoltaic Pumping Incentives and policy proposals to encourage solar water pumping in developing countries are also mentioned. It also defines possible areas for investigative follow-up.
\end{abstract}

Keywords: Agricultural; Irrigation; Water pumping; Diesel generator; Renewable Energy; Solar photovoltaic Energy; Cost analysis; Simulation; Net present Cost; Cost of Energy. 


\section{Abbreviations}

\begin{tabular}{|l|l|l|l|}
\hline BS & Battery System & $\mathrm{G}_{\mathrm{t}}$ & Actual Solar Irradiance \\
\hline CLD & Casual Loop Diagram & $\mathrm{C}_{w h}$ & Battery Capacity (Watt-hour) \\
\hline COE & Cost of Energy & $\mathrm{f}_{\mathrm{pv}}$ & Derating Factor \\
\hline CPS & Traditional Diesel Pumping System & $\mathrm{H}_{\mathrm{d}}$ & Drawdown Head \\
\hline DG & Diesel Generator & $\mathrm{P}_{\mathrm{pv}}$ & Electrical PV Output Power \\
\hline UG & Extension of the Power Grid & $\mathrm{H} 1$ & Friction Head \& Losses \\
\hline HOMER & $\begin{array}{l}\text { Hybrid Optimization Modeling for } \\
\text { Electric Renewables }\end{array}$ & $\mathrm{FC}$ & Fuel Cost \\
\hline IRR & Internal Return Rate & $\mathrm{g}$ & $\begin{array}{l}\text { Gravitational Acceleration } \\
\text { M/S }\end{array}$ \\
\hline LCC & Life Cycle Cost & (9.81 \\
\hline NPC & Net Present Cost & $\mathrm{i}$ & Interest Rate \\
\hline PV & Photovoltaic & $\eta_{v}$ and $\eta_{w h}$ & Inverter And Battery Bank Efficiency \\
\hline SPVWPS & $\begin{array}{l}\text { Solar Photovoltaic Water Pumping } \\
\text { System }\end{array}$ & $\mathrm{Y}_{\mathrm{pv}}$ : & $\begin{array}{l}\text { Load Requirement At Certain Interval } \\
\text { of Time. }\end{array}$ \\
\hline DOD & Battery Depth Of Discharge & $\eta_{\mathrm{p}}$ & Maximum PV Output Power \\
\hline CC & Capital Cost & $\mathrm{N}$ & Number Of Years (Project Life Time). \\
\hline AD & Daily Autonomy. & $\mathrm{Hp}_{\mathrm{p}}$ & Pressure Head. \\
\hline O\&MC & Operating \& Maintenance Cost & $\mathrm{P}_{\mathrm{pump}}$ & Pumping Power (W) \\
\hline RC & Replacement Cost & $\mathrm{T}_{\mathrm{c}}$ & PV Module Temperature ${ }^{\circ} \mathrm{C}$ \\
\hline SV & Salvage Cost & $\mathrm{T}_{\mathrm{c}, \text { ref }}$ & Reference Temperature \\
\hline TDH & Total Dynamic Head $(\mathrm{M})$ & $\mathrm{G}_{\mathrm{s}}$ & Standard Solar Irradiance \\
\hline a & Temperature Coefficient of Power & $\mathrm{H}_{\mathrm{st}}$ & Static Head \\
\hline Q & Volumetric Flow Rate $\left(\mathrm{M}^{3} / \mathrm{H}\right)$ & $\mathrm{C}_{\mathrm{annual}}$ & Total Annualized System Cost (\$) \\
\hline$\rho$ & Water Density (1000 Kg/ $\left.\mathrm{M}^{3}\right)$ & $\mathrm{E}_{\mathrm{total}}$ & Yearly Consumed Energy (Kwh) \\
\hline
\end{tabular}

\section{INTRODUCTION}

Water has become an increasingly scarce resource and being a major problem in many countries around the world due to water pollution, insufficient flow in some rivers and the demand as a result of growing growth, and rapid new rural and urban regions. Water pumping is an energy-intensive operation and most plants worldwide are currently powered by traditional power generation. When the prices of fossil fuels increase, their activity becomes even more costly and with the added costs of pollution and greenhouse gas emissions. In isolated agricultural areas in which electricity is needed to supply water pumping plants, diesel costs for irrigation systems are significantly inflating due to the lack of diesel on the markets, the use of diesel fuel is also more expensive due to its remoteness when used in deserted lands; solar photovoltaic modules are seen as a good option for generating electricity [1]. The efficiency of photovoltaic water pumping systems mainly depends on the capacity of the system components, which might meet the requirements of plant autonomy and the amount of water needed for irrigation.

The comprehensive algorithm to designing an optimized PV water pumping system based on real water use data is proposed [2] to investigate an optimal PV system configuration capable of supplying a solar submersible pump system to meet the residential water needs of five isolated houses located in a rural region of Morocco. Yearly simulation results showed that direct coupling appears to be an unfitting configuration for water pumping as a first selection, the second device including an MPPT DC converter with fewer PV arrays could pump more water and its performance significantly exceeded the direct coupling configuration. Furthermore, economic analysis has shown that the new systems are cost 
effective with traditional methods of water supply. In addition to photovoltaic water pumping systems, Muhsen [3] carries out a feasibility and load sensitivity study with a storage battery or diesel generator in order to achieve an optimum configuration for a reliable system. Optimum design was suggested for a standalone PV-based pumping system with a PV array capacity of $2.4 \mathrm{kWp}$ and a storage tank with a capacity of $80 \mathrm{~m} 3$. The system with the established pumps is costs of $0.05158 \mathrm{USD} / \mathrm{m}^{3}$ with average hourly volume of water about $3,297 \mathrm{~m}^{3}$ over a year. An economic and technical feasibility study for Bangladesh established optimum conditions for solar photovoltaic (PV) irrigation [4]. The optimum system is considered to be a single PV system for irrigation load of $4 \mathrm{kWh} /$ day and a PV-GeneratorBattery hybrid system for charging greater than $4 \mathrm{kWh} /$ day with storage tank capacity less than $20 \mathrm{kWh}$. The levelized COE can be as small as $\$ 0.182$, whereas PV is in service only. Replacing a single $1 \mathrm{~kW}$ diesel pump with a solar photovoltaic pump has an internal rate of return (IRR) of $12.95 \%$, a fast payback period of 9.33 years, and an equity payback rate of 8.26 years and a cost benefit ratio of 1.08 years. The net annual reduction in GHG amounts to 0.9 tons of $\mathrm{CO}_{2}$ for the project. Study of [5] presented an optimal design of the standalone solar PV-battery system for irrigation in Al Minya (Egypt). The process of optimization technique is performed using a package from HOMER. Results show that the NPC and energy costs are respectively $\$ 109,856$, and $\$ 0.059$. And for PV/BS the quantity of CO2 emissions to the DG system would be decreased by $86,511 \mathrm{~kg} / \mathrm{year}$. The energy cost to the standalone diesel system is $\$ 0.195 \mathrm{kWh}$ which is $69.74 \%$ greater than for the PV/BS system.

An effective optimization methodology for a suitable solar water pumping system which depends on the available solar irradiation, the demand for crop water, the water supply and the corresponding crop sales benefit is proposed by Aliyu [6]. Results show that optimal design would ensure continuous operations, resulting in a substantial reduction in the size of the photovoltaic array and therefore the cost of investment capital and the payback period. In another study [7], a new approach is proposed for choosing a scheduled irrigation system that minimizes the amount of photovoltaic solar panels to be installed and better matches energy consumption (calculated for specific possible combinations, supported by programming software) to the available energy obtained from panels without any power conditioning unit. Solar energy is not yet a competitive alternative relative to diesel prices, considering the production price only [8]. It's owing to strong governmental financial support for diesel from the Egyptian government. Agricultural production in developing countries is largely rain-dependent, and is adversely impacted by the lack of summer water. However, maximum solar radiation is available in summers, and this would mean that more water can be drained to meet will water demands. Given the current economic environment, in order to make solar energy a feasible alternative, government funding must decrease dramatically over the next 2 years. Laamari et al., [9] develops the optimization approach for an autonomous water pumping hybrid (wind-solar) system. This approach is focused on validated mathematical models to determine and measure the progress of different components of the hybrid system. Francisco [10] used photovoltaic, diesel and grid extension networks to exhibit the costeffectiveness of energy-efficient pumping systems in remote northern Chile. The creation of PV water pumping system for solving the problem of water supply in Indonesia is being studied [11]. The water pumping system powered by either PV panels or a diesel generator was studied to build remote areas also by Elham et al [12]. They compared the effectiveness of using the diesel units and the stand-alone PV generation taking into account the various parameters influencing both systems 'present value and other costs.

The economic and environmental assessment of the photovoltaic water pumping system (PVWPS) and the system efficiency were compared with traditional diesel pumping systems [13]. Results indicate that life cycle cost (LCC) is 29.9 percent smaller than traditional diesel costs. Via an environmental perspective, $\mathrm{CO} 2$ output for off-grid PVWPS is extremely lower than diesel system, and the $\mathrm{CO} 2$ emissions have been reduced 16.96 times in the case of extension grid mode. In regards, PVWPS leads to a reduction of about 71 percent in noise generation compared to CPS in on-grid operation. Yahyaoui et al. 
[14], designed a method of the size of the photovoltaic system elements that were installed with an energy storage unit to provide the water pumping plant with electricity.. For this farm the best results are 101.5 $\mathrm{m}^{2}$ of photovoltaic modules surface, $1680 \mathrm{Ah} / 12 \mathrm{~V}$ of battery bank and $1800 \mathrm{~m}^{3}$ of water storage tank capacity. The performance of the proposed sizing algorithm is compared with that of a commercial optimization method called HOMER that uses the proposed approach to produce better results. The economic analysis indicated that the photovoltaic- battery/pump system in Tunisia, Spain and Jordan is the optimal option. Another study [15], the development of small-scale solar irrigation was financially assessed and contrasted with that of fossil-fuel and electricity grid systems in two different climatic conditions in Iran. Life-cycle cost (LCC) approach has been used to provide financial analysis of structures. Findings show that in the scenario of 4.5 and $5.5 \mathrm{~kW}$ pumps (for citrus orchards and a vineyard, respectively) photovoltaic irrigation pumps with energy storage batteries are comparable to systems where the electricity used to drive pumps is transferred over $0.25 \mathrm{~km}$ and $1.8 \mathrm{~km}$ of private lines. While Iran depends on its heavily subsidized fossil fuels, it would not be possible to fund solar irrigation projects without the assistance of new policies and rules. Simulation analysis using PVsyst 5.52 of a design optimization of PV pumping system in Karansar, Jaipur (Rajasthan) is exhibited [16].

The outdoor measured data was used in Ghardaia, Algeria, to evaluate the efficiency of solar photovoltaic water pumping systems for different configurations of PV panels. They stated that Boutelhig et al had an optimal configuration of two modules for a $300-\mathrm{W}$ water pump and two modules for a $12.5 \%$ and $12 \%$ efficiency 130-W water pump by Boutelhig et al., [17]. Benghanem et al., [18] investigated a lot of PV configurations to improve solar-powered helical pump performance, which supplied $22 \mathrm{~m} 3$ of water per day. Their innovative findings suggested an optimum configuration of both 8 modules and 6 modules. Hamidat et al. [19] built an algorithm for assessing the efficiency of Solar PV pumping systems for different PV configurations. The results of their analysis showed the best configurations of 73 modules and 7 modules to operate a $750 \mathrm{~W}$ water pump installed in Algeria with PV system performance of 30-35 per cent. The use of diesel and electric water pumps in India annually contributes approximately 45 million tons of $\mathrm{CO}_{2}$ to the atmosphere [20], which is equal to $8 \%-12 \%$ of overall greenhouse gas emissions. To overcome these problems, the Indian Government has initiated a 0.1 million installation solar pumping system for irrigation and drinking water in 2014-2015. SPVWP's Government policies and support system are evaluated for production. A detailed study of SPVWP's key obstacles is performed with policy recommendations using causal loop diagram (CLD). García et al. [21], evaluate the environmental life cycle impacts of solar photovoltaics ( PV), grid electricity and a diesel generator as power sources for pumping water into the Spanish irrigation system. The findings demonstrate the PV as the alternative for most environmental impacts in both an off- and on-grid scenario, with lower burdens over a 30 year period. The on-grid photovoltaic option allowed excess energy exports, with six times lower environmental impacts than the off-grid option. Egyptian crop exporters are losing competitiveness on the international market due to crop losses caused by irrigation shortages [22] High carbon dioxide emissions, huge diesel discharges into the soil and precarious long-distance transport of fuel to farms are just a few of the many ecological disadvantages of diesel-fuelled water pumping systems. An alternative source of energy (solar energy) is therefore found to resolve the shortcomings of diesel powered systems and to accelerate the growth and development of Egypt's agriculture sector.

\subsection{Paper Objective}

This paper studies feasibility analysis, efficiency evaluation and optimum sizing of water pumping system consisting of three options: diesel system, off-grid PV/battery system, and PV/Grid system extension grid comparison. The mainly objective of this study is to present a detailed comparison study in scientific, economic, and environmental terms between conventional diesel pumping system and solar water pumping system. Additionally, the pumping power required for the proposed system has been estimated in this research with the goal of supplying water demand in the human and irrigation needs of the isolated agricultural area at El Garaq site in Fayoum City, Egypt. The study focuses on technoeconomic aspects for selecting a pumping system design with high reliability from different proposed 
systems to reduce the cost of the system's life cycle. For every hour of a year, an energy balance calculation is performed to achieve a perfect pumping system configuration for a certain load at a selected site. The optimization-based process is carried out using the software package of HOMER 3.13.8. The optimization performance of the off grid solar PV/battery power system is compared with those outcomes from convention diesel and PV extension grid systems. The paper is organized as follows: Section 2 presents methodology details of geography location, solar resource data and load requirement profile. Section 3 describes the system components. Section 4 illustrates system modeling using HOMER package. Section 5 shows the findings of three possible systems, which are the on-grid system for diesel/pump, PV/batteries/pump off-grid, and PV/pump. Also pumping power capacity is estimated in section 5. Finally, the research paper is concluded in Section 6.

\section{METHODOLOGY}

\subsection{Geographical Location Data}

Fayoum is a city in Middle Egypt. Located 100 kilometers (62 miles) southwest of Cairo, in the Fayoum Oasis, it is the capital of the modern Fayoum Governorate. South of the Fayoum Oasis, a smaller depression contains the town of El Gharaq. It is also irrigated from the Nile. This study focuses on this agriculture remote location of El Gharaq town in Etsa region, Fayoum City. However, in this area there are some small spread communities which make it impossible to provide electricity through the grid system. The stand-alone photovoltaic pumping system will enable these communities to supply electricity and improve their livelihood and irrigate crops. Figure 1 [23] shows the selected site map of El Gharaq town in Etsa region, Fayoum, Egypt at latitude of $29^{\circ} 23^{\prime}$ North and longitude of $30^{\circ} 78^{\prime}$ East, with elevation of 12 above sea level.

\subsection{Weather Data}

Even though PV systems directly convert solar radiation into electric power through the photovoltaic effect, the PV system's performance increases with the incidence of solar radiation on its surface. Egypt is situated in the Sunbelt zone, ensuring very high levels of irradiation and optimum sunshine hours during the year with $2000 \mathrm{kWh} / \mathrm{m}^{2} /$ day annual global radiation [24],[25]. The irradiance distribution is sufficient for the case study proposed. For this case study, the hourly solar radiation and temperature data are collected from 2010-2018 of National Aeronautics and Space Administration (NASA) organization, and then the mean monthly solar radiation, ambient temperatures are calculated as shown in table 1 [26]. The average time per day of sunlight is about $9 \mathrm{hrs}$ in summer season and $4 \mathrm{hrs}$ in winter [27]. Based on the data collected, this case study can be observed to have huge potential for solar photovoltaic applications. The performance solar power is based on the panel's horizontal direction, and also the azimuth angle. In Egypt, the solar photovoltaic system would face the sun toward the south. Changing the azimuth angle of the system (the angle between the normal to the planet and the south direction) influences the rate of irradiation in every solar system. Optimum tilt angle for this site is $25^{\circ}$ and zero for azimuth angle.

As shown in table 1, it is clear that the selected site has considerably average radiation of 219.55 $\mathrm{kWh} / \mathrm{m}^{2} /$ month and maximum value is about $564 \mathrm{kWh} / \mathrm{m}^{2} /$ month in the month of September while the minimum value is $114.38 \mathrm{kWh} / \mathrm{m}^{2} /$ month in December. That corresponds to higher power and water demand periods. Also, the highest temperature value occurred especially in summer months of $30^{\circ} \mathrm{C}$ and the lowest temperature in winter is $12^{\circ} \mathrm{C}$. These temperature values affects strongly in PV Production. These low rates reduce the structural and mechanical costs of the system, and minimize sand particle movement. This can help secure the PV modules' glass cover against scratch. 


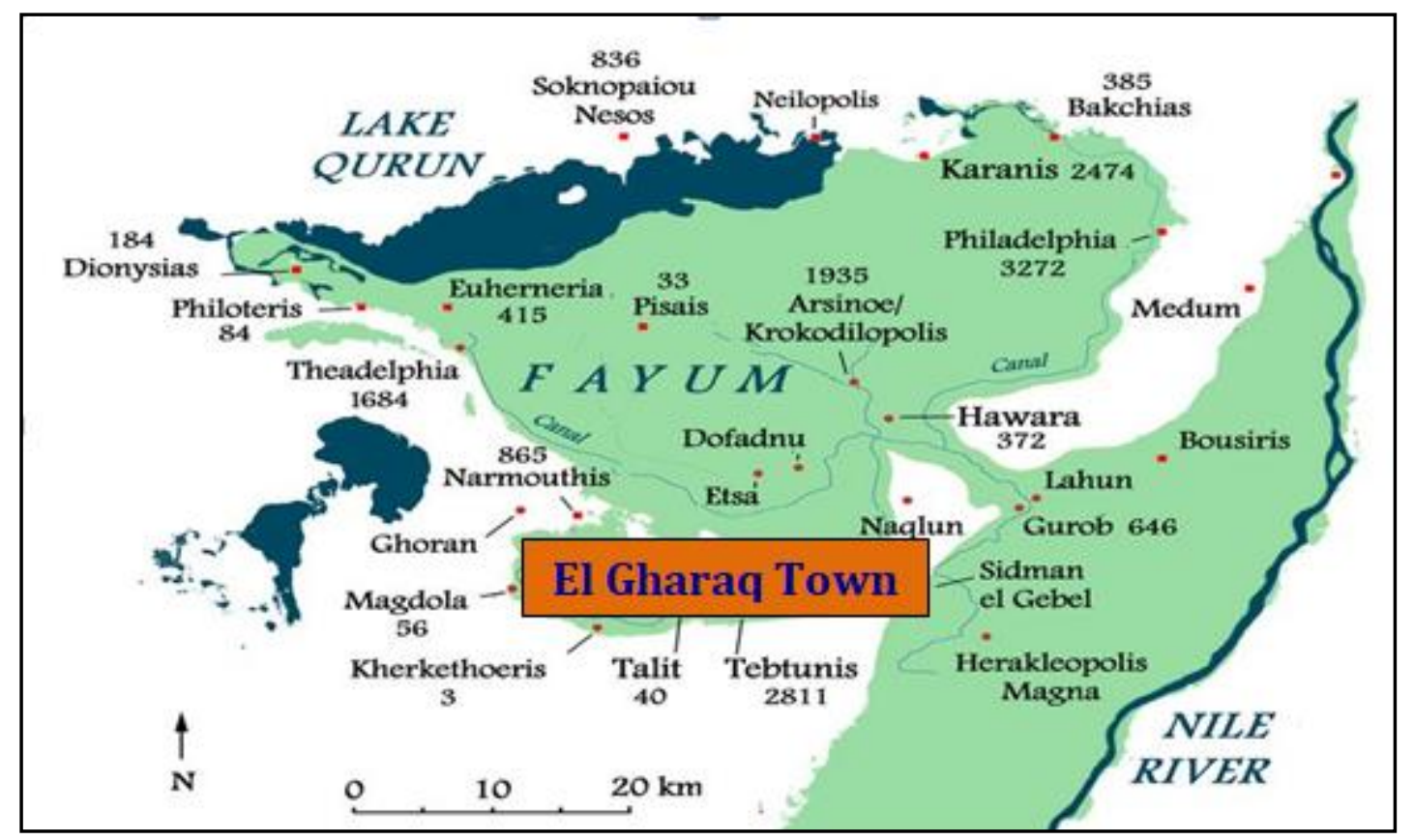

Fig.1: Geographical location for El Gharaq Town, Etsa Region, Fayoum City, Egypt [23]

Table 1: Monthly Average Solar Radiation \& Ambient Temperature of El Gharaq Location (2010-2018) [26]

\begin{tabular}{|c|c|c|}
\hline Month & $\begin{array}{c}\text { Solar Radiation } \\
\left(\mathrm{kWh} / \mathrm{m}^{2} / \text { day }\right)\end{array}$ & $\begin{array}{c}\text { Temperature } \\
\left({ }^{\circ} \mathrm{C}\right)\end{array}$ \\
\hline January & 122.674 & 12.68 \\
\hline February & 134.572 & 14.72 \\
\hline March & 188.248 & 18.78 \\
\hline April & 220.112 & 22.86 \\
\hline May & 244.1 & 27.26 \\
\hline June & 250.942 & 29.86 \\
\hline July & 259.062 & 30.28 \\
\hline August & 241.544 & 30.68 \\
\hline September & 564.992 & 28.72 \\
\hline October & 168.654 & 24.72 \\
\hline November & 125.42 & 19.86 \\
\hline December & 114.38 & 14.26 \\
\hline Average & 219.5583 & 22.89 \\
\hline
\end{tabular}

\subsection{Water Requirement Load Profile:}

Identifying the amounts of water consumption during the irrigation season is critical when deciding the exact amount of water flow needed to determine the optimum size of the pump. In this case study, the maximum daily required water demand of three categories: inhabitant residential, live stock (cow, horse, chicken) and irrigation crops (rice, tritium, vegetables, sugar cane) is $726 \mathrm{~m}^{3}$. The average daily load profile fluctuates from season to season, where in summer, winter, respectively; it is 3975 and 3812 $\mathrm{kWh} /$ day. Rainfall, groundwater, or spring irrigation can administer the need for water from the crops. Moreover, the net demand for irrigation water should be estimated to eliminate the losses due to crop evapo-transpiration and substantial percolation. The estimation of the load profile of water requirements in the summer and a winter season throughout the day is shown in figure 2.

\section{SYSTEM COMPONENTS DESCRIPTION}

The proposed standalone system consists of two: diesel system, PV/battery off-grid system and comparing with extension grid of PV/Grid system that comprises PV panels, battery bank, diesel generator, pump and inverter. First system only comprises of a convention diesel which supplies 
electricity to the water pump and the second system, the pump is supplied via PV modules while the third system the PV modules and the battery bank supply the pump with the electricity. The different elements of the proposed system are shown in figure 3 and explained as follows:

\subsection{PV Module}

The corresponding PV power Ppv, thus forming the Ppv (G; Ta) sequence are shown in equation 1 [28]:

$$
\mathrm{P}_{\mathrm{pv}}(\mathrm{W})=\mathrm{f}_{\mathrm{pv}} \times \mathrm{Y}_{\mathrm{pv}} \times \frac{G t}{G s} \times\left[1+\mathrm{a}\left(\mathrm{T}_{\mathrm{c}}-\mathrm{T}_{\mathrm{c}, \mathrm{ref}}\right)\right]
$$

Where; $\mathrm{P}_{\mathrm{pv}}$ : electrical power of PV output, $\mathrm{Y}_{\mathrm{pv}}$ : full capacity of PV output power, $\mathrm{f}_{\mathrm{pv}}$ : PV derating factor, $\mathrm{G}_{\mathrm{t}}$ : real solar irradiance, $\mathrm{G}_{\mathrm{s}}$ : normal solar irradiance, a: coefficient of power temperature and $\mathrm{T}_{\mathrm{c}, \text { ref }} \& \mathrm{~T}_{\mathrm{c}}$ : reference and $\mathrm{PV}$ module temperature ${ }^{\circ} \mathrm{C}$.

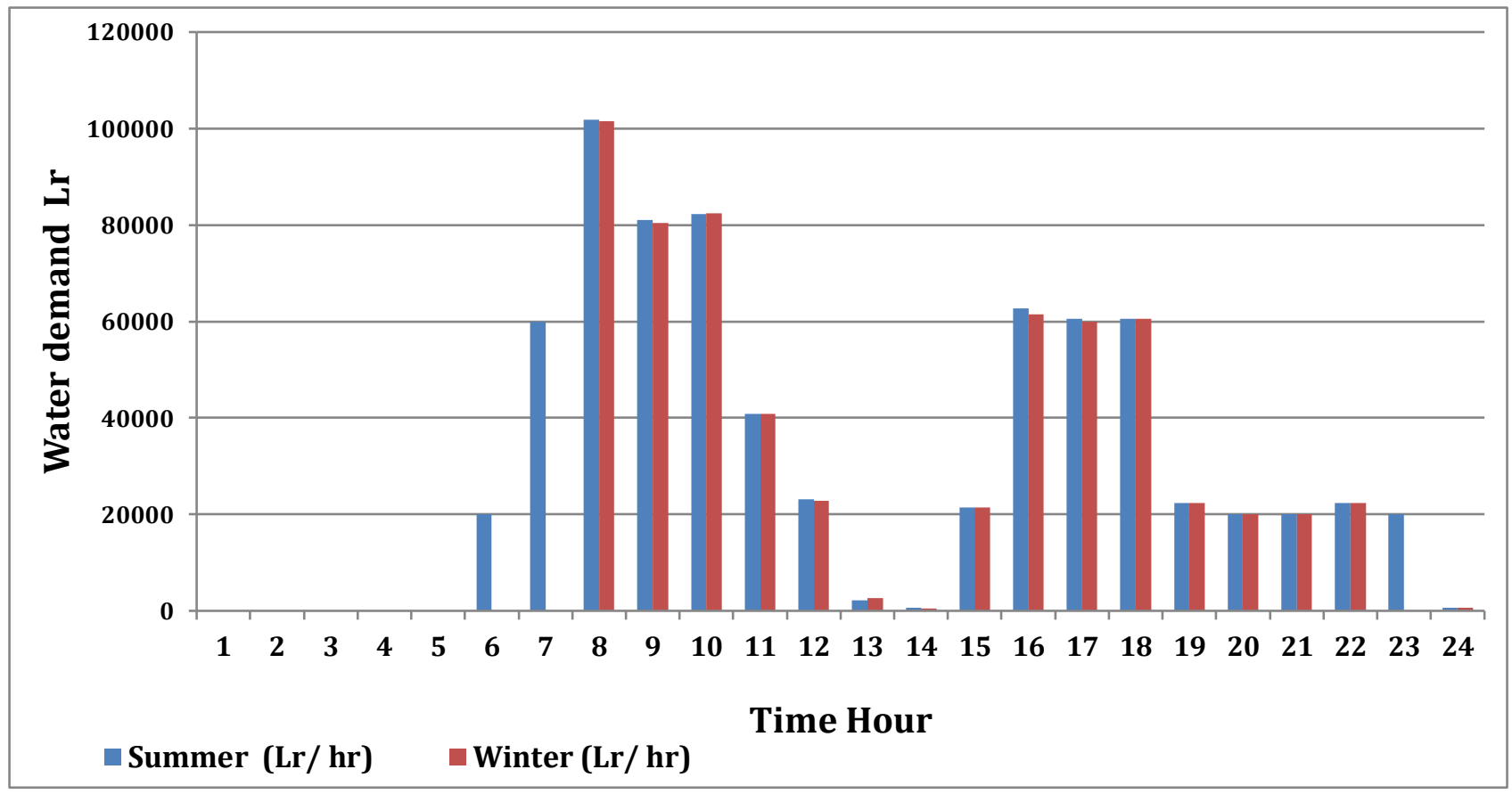

Fig. 2: Daily Load Profile Water Energy Consumption Requirements of El Gahraq Site

\subsection{Battery Bank}

In an isolated area, the battery can be used as energy storage as well as the lead acid battery is widely used in renewable energy systems. The battery capacity can be estimated using the equation below [5], [28]:

$$
\mathrm{C}_{w h}=(\mathrm{EL} \times \mathrm{AD}) /\left(\eta_{v} \times \eta_{w h} \times \mathrm{DOD}\right)
$$

Where: $\mathrm{C}_{w h}$ : Battery Capacity (Watt-hour)

AD: daily autonomy.

EL: load requirement at certain interval of time.

$\eta_{v}$ and $\eta_{w h}$ : inverter and battery bank efficiency respectively.

DOD: Battery depth of discharge is specified and not to be exceeded

\subsection{Diesel Generator}

It is common to use diesel to power generators in agricultural operations. There are also significant disadvantages when using propane or bottled gas to heat water for cleaning or crop processing applications, or when heating air for crop drying, including transport to the place where the heat is required, fuel costs and safety problems. Diesel generator is used for generating electricity in remote area. In case of off-grid system, diesel generator is used as a backup if the renewable sources are insufficient to supply the load. 


\subsection{Pump Motor}

That is the core of the pumping system for solar water. Solar pumps are rated by the voltage of the electricity to be supplied. Equation 3 indicates the pump 's power according to certain important parameters [13], [29], [30]:

$$
\mathrm{P}_{\text {pump }}=\frac{\rho \times g \times Q \times T D H}{\eta p \times 3600}
$$

$\mathrm{P}_{\text {pump }}, \rho, \mathrm{g}, \mathrm{TDH}, \eta \mathrm{p}$, and $\mathrm{Q}$ are pumping power $(\mathrm{W})$, water density $\left(1000 \mathrm{~kg} / \mathrm{m}^{3}\right)$, gravitational acceleration $\left(9.81 \mathrm{~m} / \mathrm{s}^{2}\right)$, total dynamic head $(\mathrm{m})$, motor-pump efficiency $(\%)$, and volumetric flow rate $\left(\mathrm{m}^{3} / \mathrm{h}\right)$, respectively. Total dynamic head TDH $(\mathrm{m})$ and flow rate $\mathrm{Q}\left(\mathrm{m}^{3} / \mathrm{hr}\right)$ should be specified accurately to select the suitable pump. The total dynamic head TDH could be expressed as in equation 4 [29]:

$$
\mathrm{TDH}(\mathrm{m})=\mathrm{H}_{\mathrm{st}}+\mathrm{H}_{\mathrm{d}}+\mathrm{H}_{1}+\mathrm{H}_{\mathrm{p}}
$$

Where: $\mathrm{H}_{\text {st }}$ : Static Head, $\mathrm{H}_{\mathrm{d}}$ : Drawdown Head, $\mathrm{H}_{1}$ : Friction head \& Losses and Hp: Pressure Head.

\subsection{Inverter}

The power flow between the two buses $\mathrm{AC}$ and DC requires an inverter. It shifts the direct current from the solar panels into alternating current for the pump and the control system generally provides low voltage protection, whereby the system is switched off if the voltage for the operating voltage is too low or too high of pump. The endorsed inverter power range ranges from 0.15 to $55 \mathrm{~kW}$ [31], and can be used for larger irrigation systems. However, the panel and inverters need to be sized to accommodate an AC motor's over-current characteristics.

\subsection{Water Tank: it is used as storage of water.}

\section{SYSTEM MODELING}

During the needed pumping time, efficient water pumping system optimization process should satisfy the electrical power needed to supply the water pump. The sizing algorithm purpose is to ensure that the pump is supplied during the day in such a way as to protect the battery bank from deep discharge or excessive charging and to ensure the water required for human needs, live stock crops and irrigation. The aim of this optimization model is to minimize the net present cost, while minimizing the cost of the generated energy. The proposed system investigates diesel system, off-grid PV/battery system, and compares to PV/Grid system extension grid. First system only comprises of a convention diesel which supplies electricity to the water pump and the second system, the pump is supplied via PV modules while the third system the PV modules and the battery bank supply the pump with the electricity. The sizing algorithm's inputs, outputs, targets and parameters are illustrated as follows, using HOMER software.

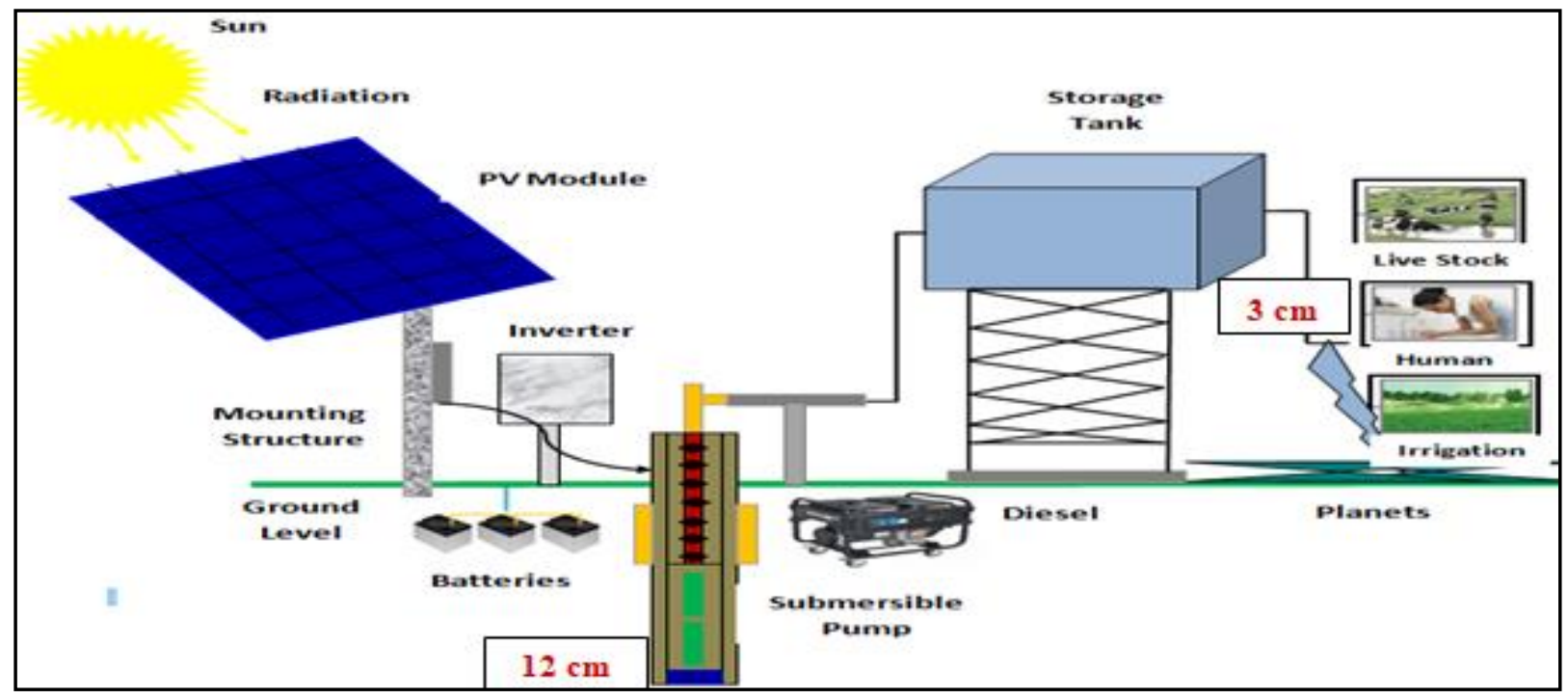

Fig. 3: Proposed System Description Components 


\subsection{Simulation Using HOMER Software}

This segment explores and compares the efficiency of the stand-alone power generation systems for underground water pumping purposes, both diesel and solar PV. The simulation and optimization process are performed using commercial software from HOMER 3.13.8 software package; developed by the National Laboratory for Renewable Energy (NREL) is used as a simulation tool. Using HOMER package, the transient model and system simulations were carried out [32]. The feasibility of HOMER simulations for evaluating the plant efficiency of water pumping systems was demonstrated by [5], [14]. The optimization of the system is then defined, following by the simulation results and discussion. A schematic of diesel off-grid system supplying load pattern is shown in figure 4.a. and PV/battery off grid system is illustrated in figure 4.b while figure 4.c presents PV on-grid system. The components data used in this simulation are exhibited in Table 2.

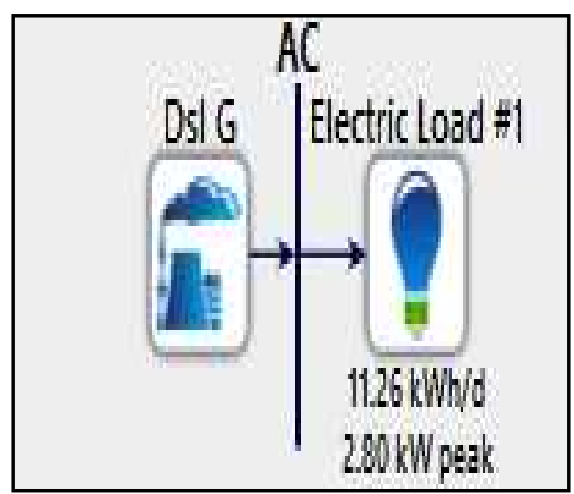

a. Diesel System

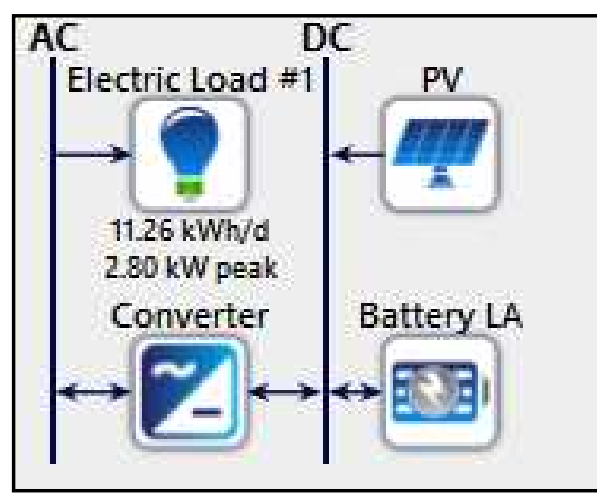

b. PV/Battery Off-Grid System

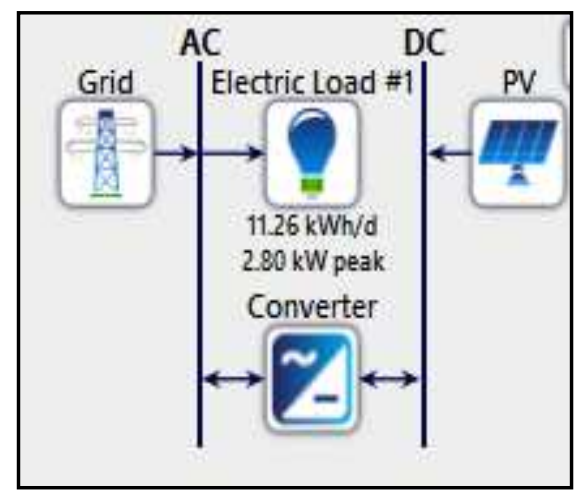

c. PV/On-Grid System

Fig. 4: On/Off-Grid Solar Power Pumping System Scheme Implemented In HOMER

Table 2: Components Data Used in Simulation

\begin{tabular}{|l|c|c|c|c|c|}
\hline Component & Capacity (kW) & Capital Cost (\$) & Replacement Cost (\$) & O/M Cost (\$/Yr) & Life Time (Yr) \\
\hline Solar PV & 1 & 3000 & 3000 & 10 & 25 \\
\hline Battery & $\begin{array}{c}83.4 \mathrm{Ah}, 12 \mathrm{~V} \\
800 \mathrm{kWh} \\
\text { throughput }\end{array}$ & 300 & 300 & 10 & 10 \\
\hline $\begin{array}{l}\text { Diesel } \\
\text { Generator }\end{array}$ & 1 & 500 & 500 & $0.03(\$ / \mathrm{hr})$ & $15000 \mathrm{hr}$ \\
\hline Converter & 1 & 300 & 300 & 5 & 15 \\
\hline
\end{tabular}

- Fuel Price: $0.2 \$ / \mathrm{L}$ according to Egyptian Markets

- Extension of Grid: capital cost 10000 \$/km, Grid Power Price: 0.1 \$/kWh, 0 Grid Sellback Price: 0.05 $\$ / \mathrm{kWh}[33]$

Two indicators; NPC and COE are used to evaluate the optimal on/off grid water pumping system configurations. NPC indicates the life-cycle costs of the system, including cost of capital, construction, cost of O\&M, and cost of salvage which represents the cost of residues left at the end of the project of every factor in the project. NPC stands for the following equation [5], [32], [34]. The results of the simulation using HOMER Software will be shown in the following section of results.

$$
\text { Min } \mathrm{Z}=\sum \text { Net Present Costs (NPC) } \mathrm{NPC}=\left(\mathrm{CC}+\sum_{\mathrm{i}=1}^{\mathrm{N}} \frac{(\mathrm{RC}+\mathrm{O} \& M C+F C-S V)}{(1+\mathrm{i})^{\mathrm{N}}}\right)(\$)
$$

Where, CC: Capital Cost, RC: Replacement Cost, O\&MC: Operating \& Maintenance Cost, FC: Fuel Cost, SV: Salvage Cost, i: Interest Rate, and N: Number of Years (project life time). Also, the cost of energy formula can be expressed as in equation 6 [5], [32]:

$$
\mathrm{COE}=\frac{\text { Cannual }}{\text { Etotal }}
$$


Where; $\mathrm{C}_{\text {annual: }}$ total annualized system cost $(\$)$ and $\mathrm{E}_{\text {total }}$ : yearly consumed energy $(\mathrm{kWh})$; Parameters Assumptions in this study:

- Max. Allowable Shortage $=5 \%$ (which is acceptable for the current case study).

- Min. Renewable Fraction $=75 \%$.

- Annual Real Interest Rate $=6 \%$. (10-4), inflation rate=4\%; (According to Egyptian banks)

- Project Life Time: 25 Year, and -Dispatch Strategy: Load Following (LF)

\section{RESULTS \& DISCUSSION}

\subsection{Optimization Results of HOMER}

In this section, the overall water pumping system costs including initial investments and operational costs for three different system installations are compared. Table 3 summarizes the findings of simulation/optimization for on/off grid water pumping system in regards total net present cost ( NPC) and energy cost (COE). Monthly Electric Production of the optimum water pumping system is illustrated in figure 5 .

Table 3: Optimization Results of Water Pumping System for On/Off Grid Systems

\begin{tabular}{|l|l|l|l|l|c|c|c|}
\hline System & \multicolumn{1}{|c|}{$\begin{array}{c}\text { Configurations } \\
\text { Capacity }\end{array}$} & $\begin{array}{l}\text { NPC } \\
(\$)\end{array}$ & $\begin{array}{l}\mathrm{COE} \\
(\$ / \mathrm{kWh})\end{array}$ & $\begin{array}{l}\mathrm{RF} \\
(\%)\end{array}$ & $\begin{array}{c}\text { Shortage } \\
(\%)\end{array}$ & $\begin{array}{l}\text { Excess Electricity } \\
(\%)\end{array}$ & $\begin{array}{l}\mathrm{CO}_{2} \\
(\mathrm{~kg} / \mathrm{yr})\end{array}$ \\
\hline Diesel Off-Grid & DSL: $3.10 \mathrm{~kW}$ & 35,144 & 0.434 & 0 & 0 & 32.3 & 6,648 \\
\hline PV/Battery Off-Grid & $\begin{array}{l}\text { PV: } 3.83 \mathrm{~kW} \\
\text { Battery: } 10 \mathrm{Units} \\
\text { Converter:1.71 kW }\end{array}$ & 26,295 & 0.332 & 100 & 5 & 19.2 & 0 \\
\hline $\begin{array}{l}\text { PV On-Grid } \\
\text { Extension }\end{array}$ & $\begin{array}{l}\text { PV: } 2.57 \mathrm{~kW} \\
\text { Grid: } 1000 \mathrm{~kW} \\
\text { Converter:2.11 kW }\end{array}$ & $\mathbf{9 , 7 9 6}$ & $\mathbf{0 . 0 7 7}$ & 75.1 & 0 & 0.00 & 1098 \\
\hline
\end{tabular}

From table 3; it is clear that PV On-Grid is the optimal water pumping system for the chosen site as it has the lowest net present cost and energy cost of $\$ 9796$ and $\$ 0.07 / \mathrm{kWh}$, respectively. The optimum configuration capacities of this PV On-Grid system are $2.57 \mathrm{~kW}$ of solar PV panels and $2.11 \mathrm{~kW}$ of converter that meets zero shortage and $75.1 \%$ renewable fraction. Also, PV On-Grid system has least $\mathrm{CO}_{2}$ emissions while the diesel off-grid system will add around $6648 \mathrm{~kg} / \mathrm{yr}$.

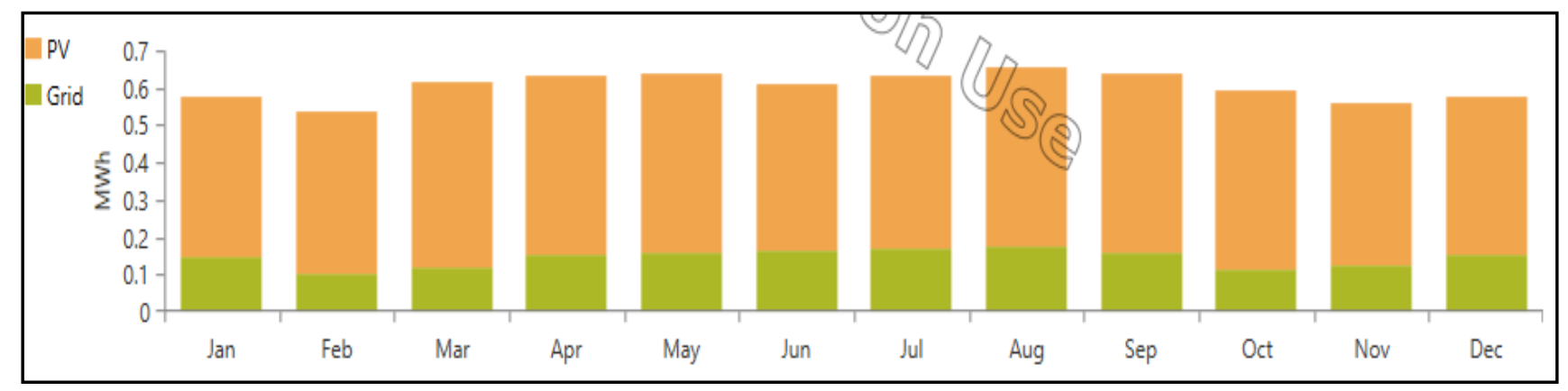

a. PV On-Grid System

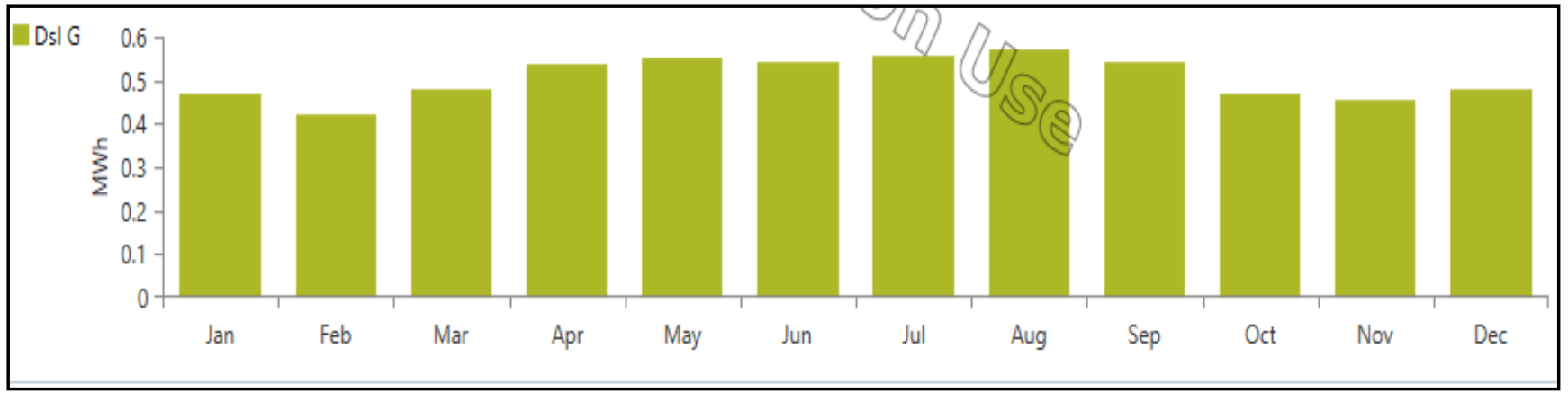

b. Diesel System 


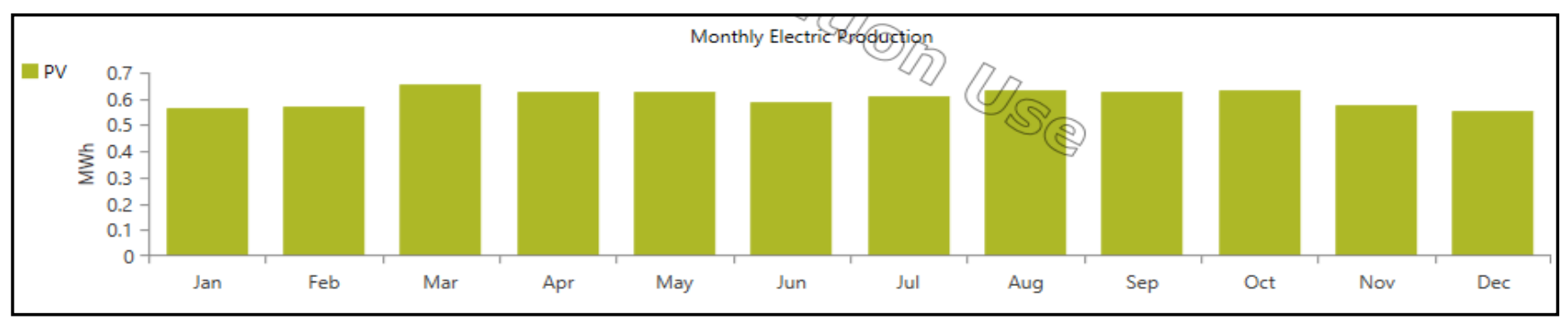

c. PV/Battery Off-Grid System

Fig. 5: Monthly Electric Production of the Optimum Water Pumping System

From figure 5; it is found that PV electric energy production share is $76.1 \%$ while grid purchased energy from the national grid is $23.9 \%$ in 6-a while share of electric energy production by diesel is $100 \%$ in 6-b and $100 \%$ by PV only in 6-c. There no excess energy electricity; in case of PV/On-Grid system while it is $32.3 \%$ in Diesel Off-Grid system and 36.2\% in case of PV/Battery Off-Grid system and we can doing load management for this excess energy. The importance of excess energy is not evaluated straight away, as it depending on other system components such as PV panel power, energy storage and converter in addition to the average annual intensity of available global solar radiation. In PV On-Grid system; this electric production served the defined load with $58.9 \%(4109 \mathrm{kWh} / \mathrm{yr})$ and the rest of $41.1 \%$ is sold to the national grid. Also, high value of PV electric energy production was in March and August months due to high solar radiation in these months at the selected site, hence the lowest values of purchased electricity from national grid. The monthly electric energy values purchased or sold of grid are presented in table 4 while hourly values are illustrated in figure 6.

Table 4: Monthly Electric Energy Purchase/Sold kWh of National Grid

\begin{tabular}{c|c|c}
\hline Month & $\begin{array}{c}\text { Energy Purchased } \\
(\mathbf{k W h})\end{array}$ & $\begin{array}{c}\text { Energy Sold } \\
(\mathbf{k W h})\end{array}$ \\
\hline January & 146 & 240 \\
\hline February & 104 & 234 \\
\hline March & 118 & 260 \\
\hline April & 155 & 246 \\
\hline May & 160 & 240 \\
\hline June & 164 & 219 \\
\hline July & 167 & 234 \\
\hline August & 176 & 242 \\
\hline September & 161 & 245 \\
\hline October & 111 & 253 \\
\hline November & 123 & 230 \\
\hline December & 153 & 228 \\
\hline Annual & 1,738 & 2,871 \\
\hline
\end{tabular}
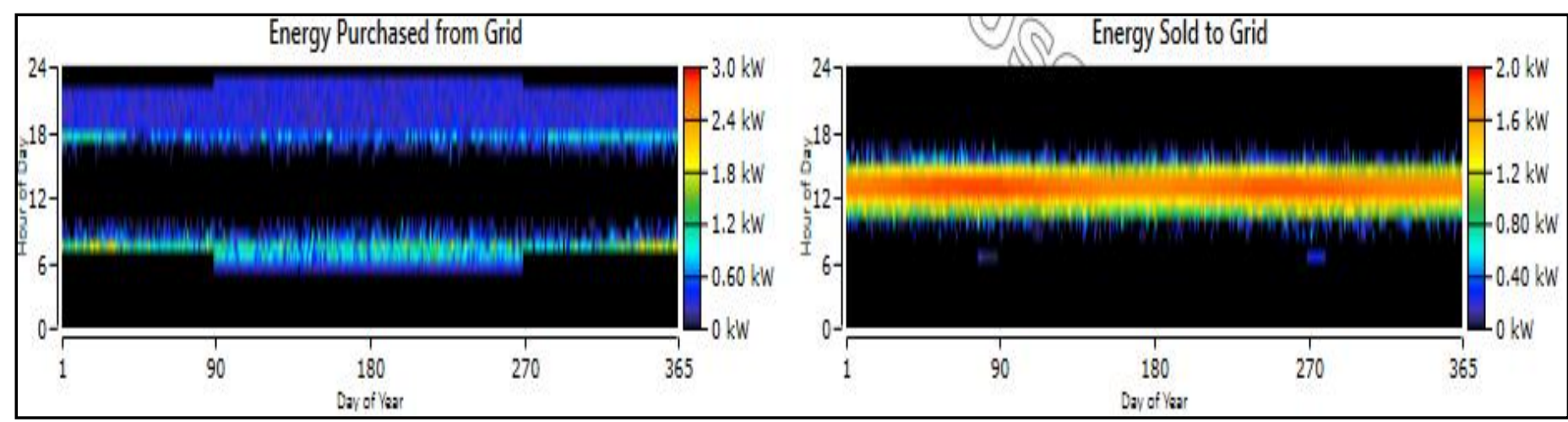

Fig.6: Hourly Electric Energy Purchase/Sold kWh of National Grid whole the year

The hourly PV/inverter power output of on-grid system is indicated in figure 7-a while PV output /inverter power/state of charge of PV-battery off-grid systems is exhibited in figure 7-b. Also, hourly fuel consumption values of diesel system hourly are shown in figure 8. Figure 9 presents cash flow Diagram for these investigated water pumping systems. 

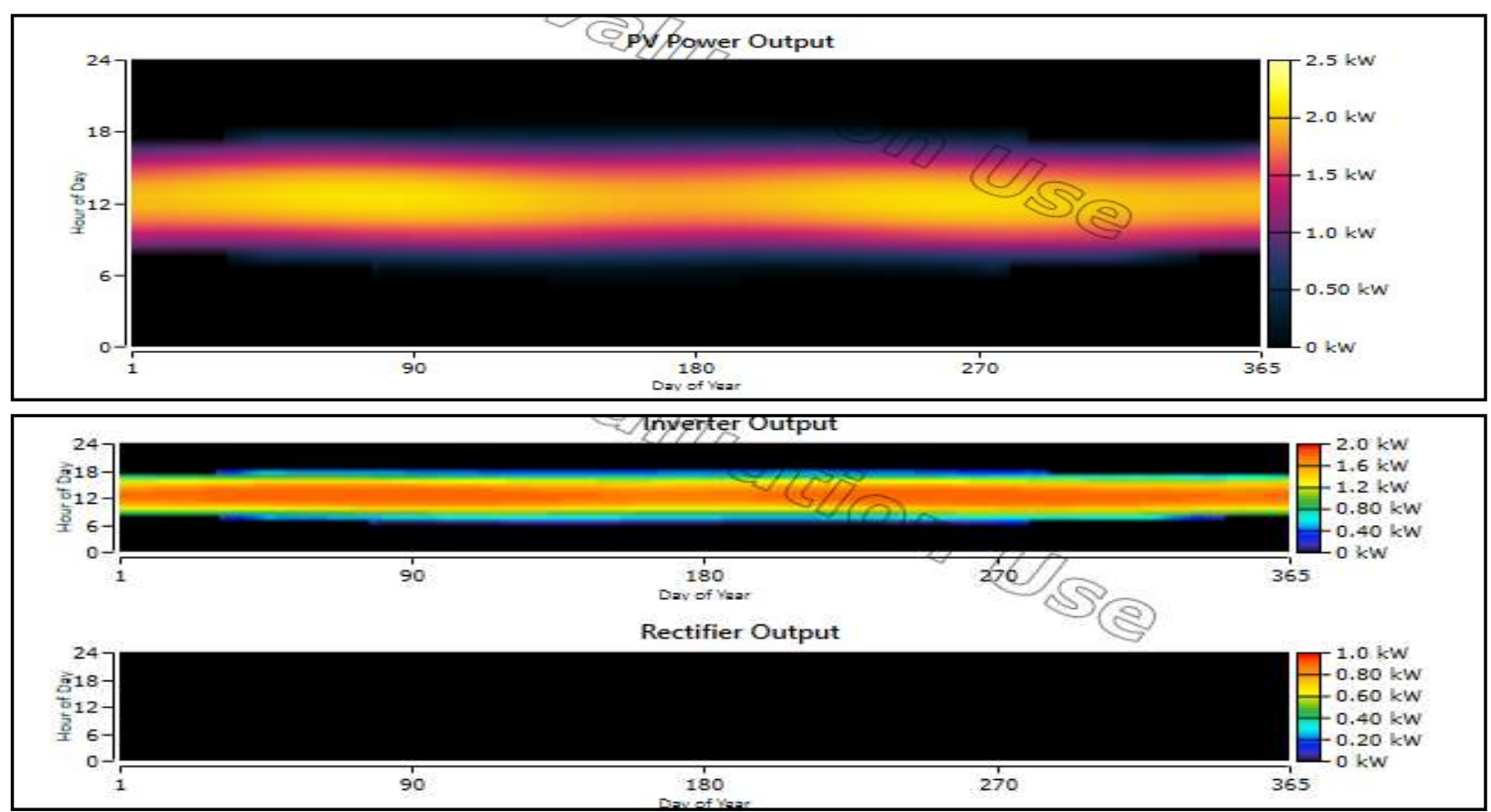

a- On-grid System
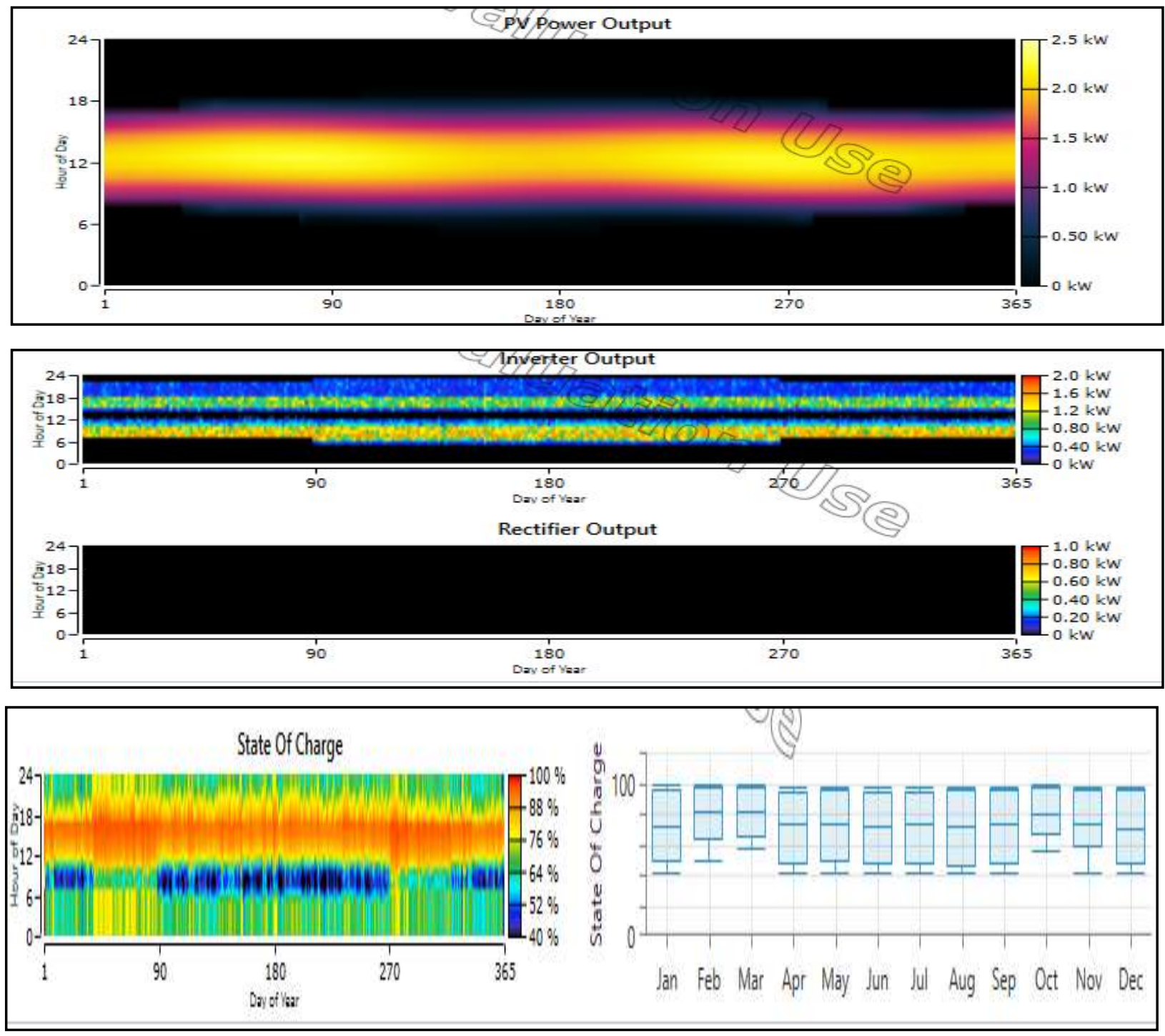

b- PV-Battery Off-grid System

Fig.7: Hourly PV/inverter power Output of On/Off -Grid System Water Pumping System 


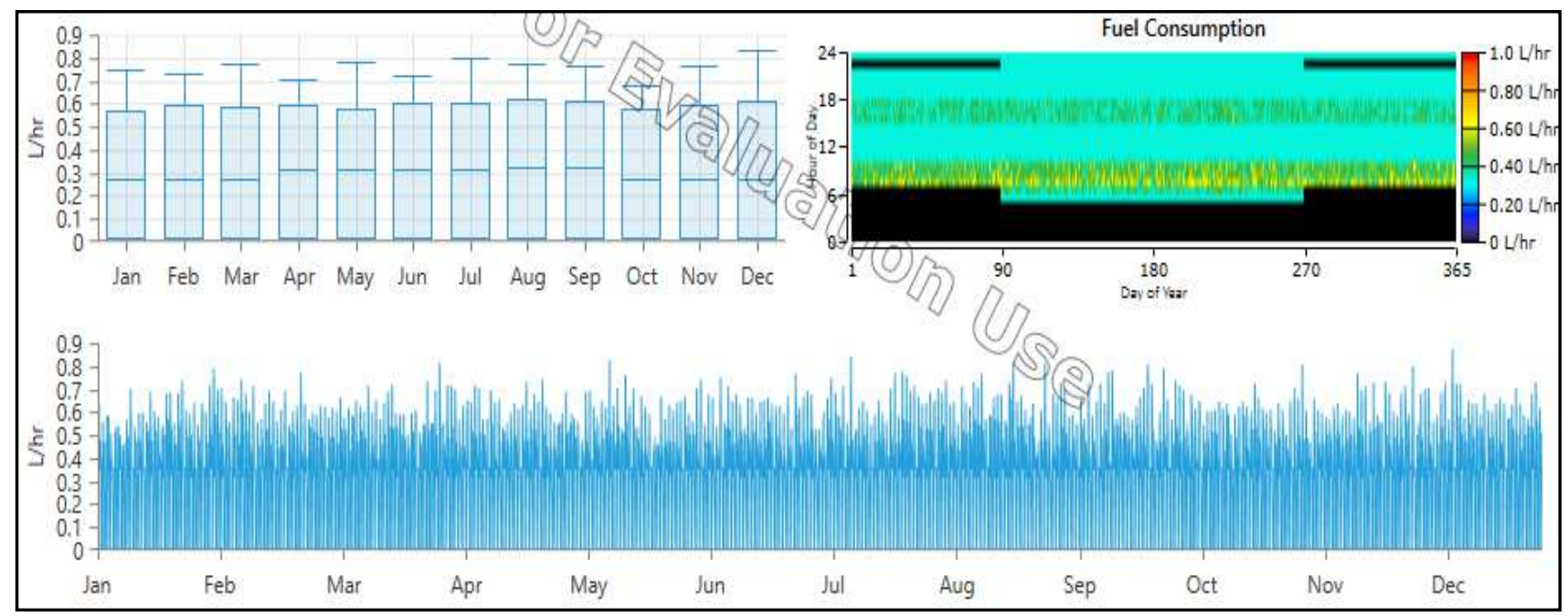

Fig.8: Hourly Fuel Consumption Whole the Year of diesel Water Pumping System

From figure 7-b; it is noticed that PV power output is high of $1.6 \mathrm{~kW}$ at 12 o'clock, inverter output 1.4 $\mathrm{kW}$ and also state of battery charge is around $80 \%$ while at 5 o'clock the PV output is low 0.3 of $\mathrm{kW}$ and stat of charge battery is almost $40 \%$. In figure 8, it is clear that diesel generator power is operating from 7 o'clock to 23 due to load profile is high in these times and fuel consumption is high at 20 o'clock.

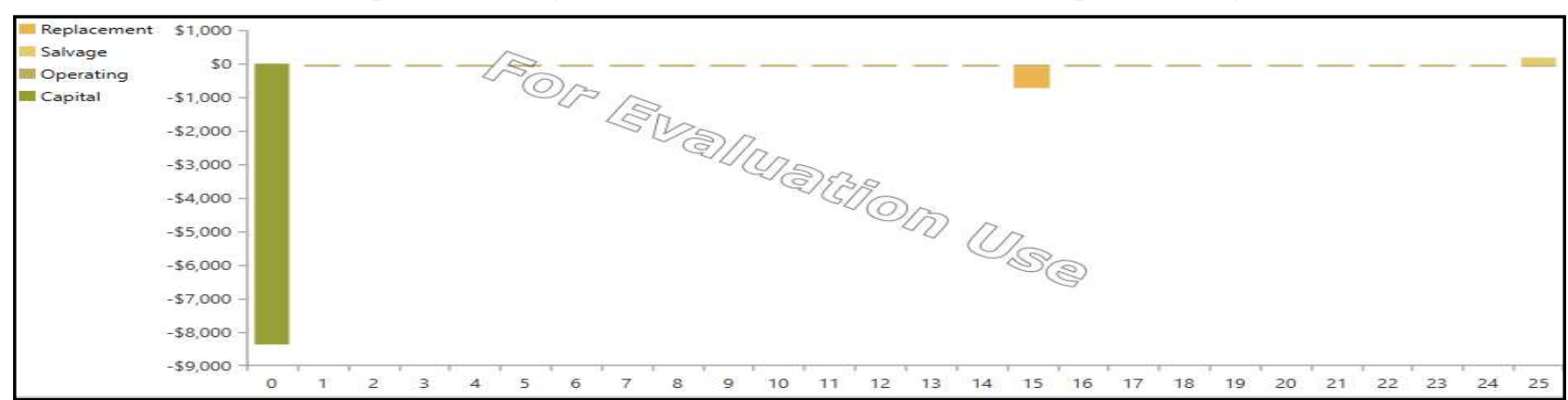

a. PV On-Grid System

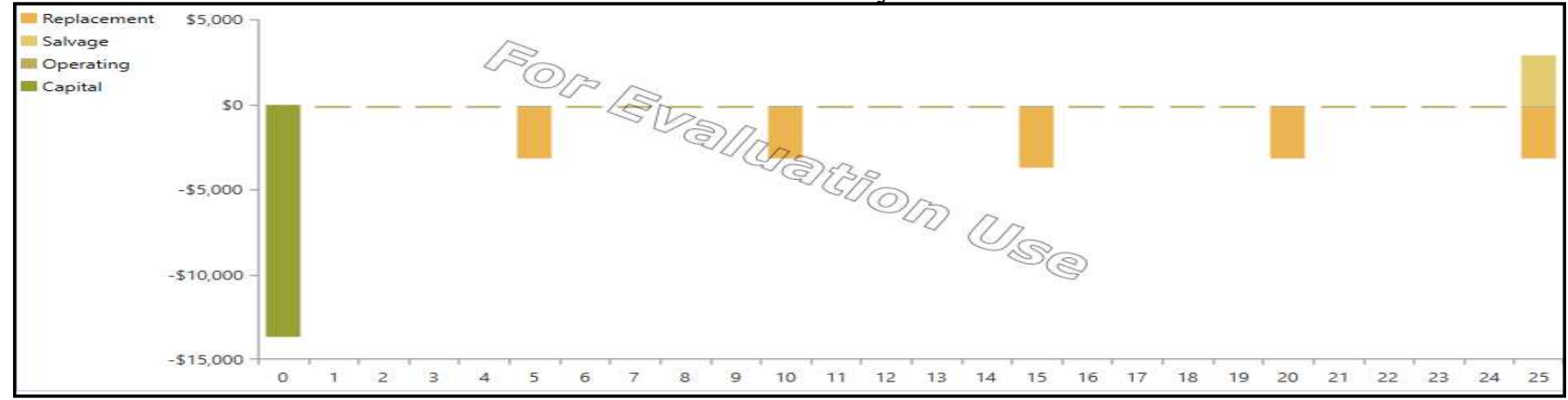

b. PV/Battery Off-Grid System

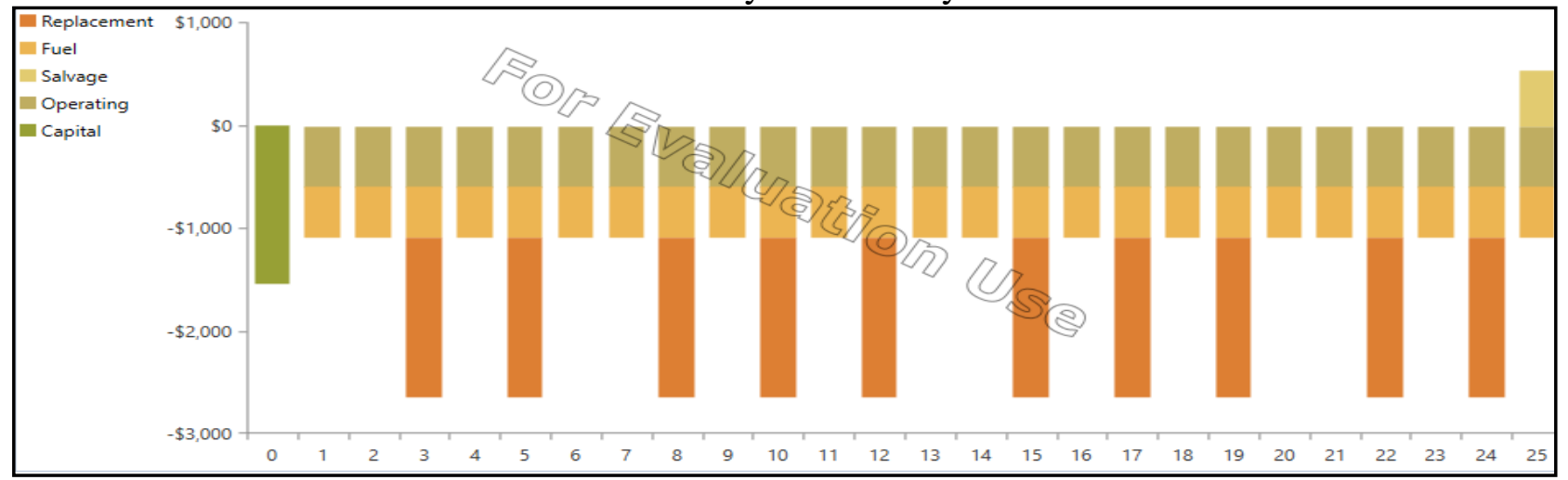

c. Diesel System

Fig. 9: Cash flow Diagram of the Optimum Water Pumping System 
From figure 9; it is noticed the capital cost of diesel off-grid system is lower than the PV on-grid system and PV/Battery off-grid system while it has higher cost for replacement and operating/maintenance than other two systems. Although the salvage value of Diesel off-grid and PV/Battery off-grid systems is higher that PV on-grid system, it has no significant effect on the life time NPC or COE. The optimization surface plot (NPC\&COE indicators) of on-grid and PV-battery off-grid system are shown in figure 10.

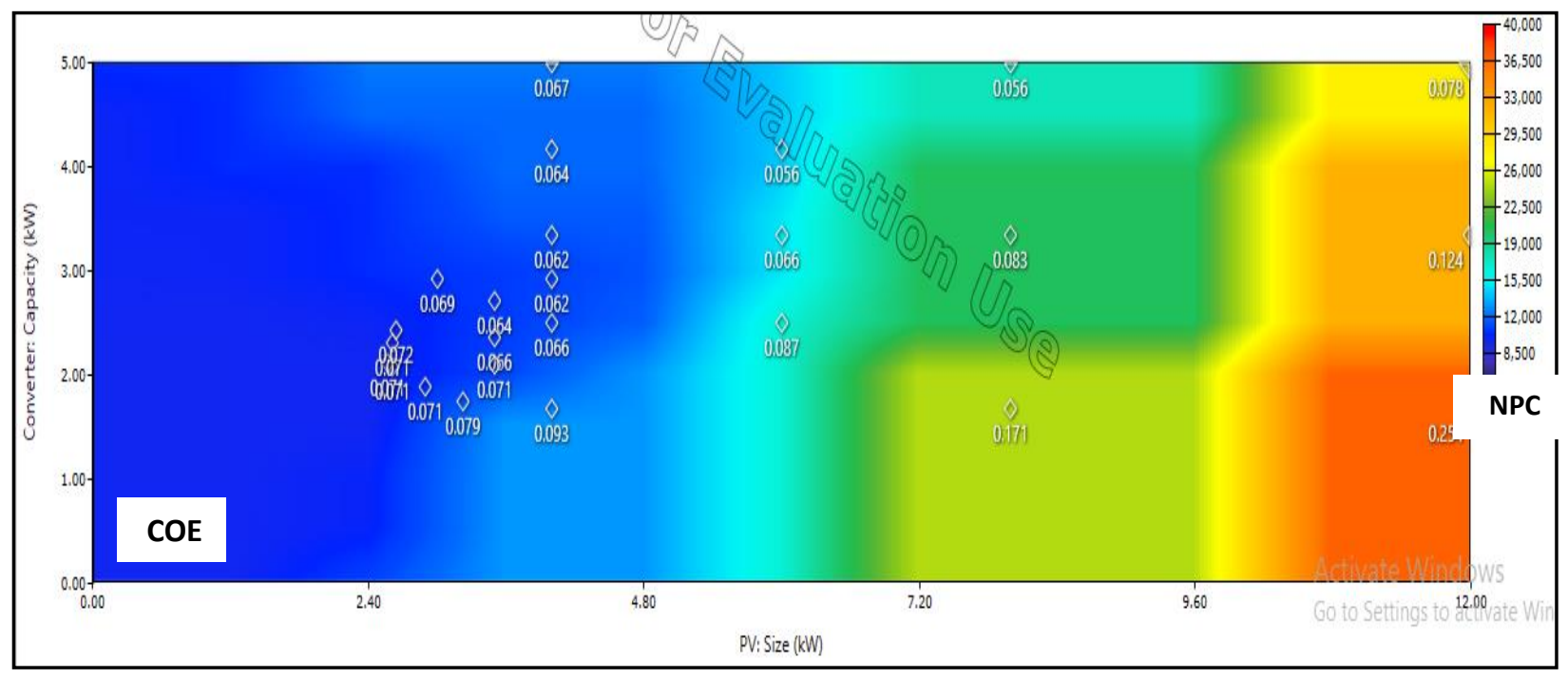

a- On-grid system

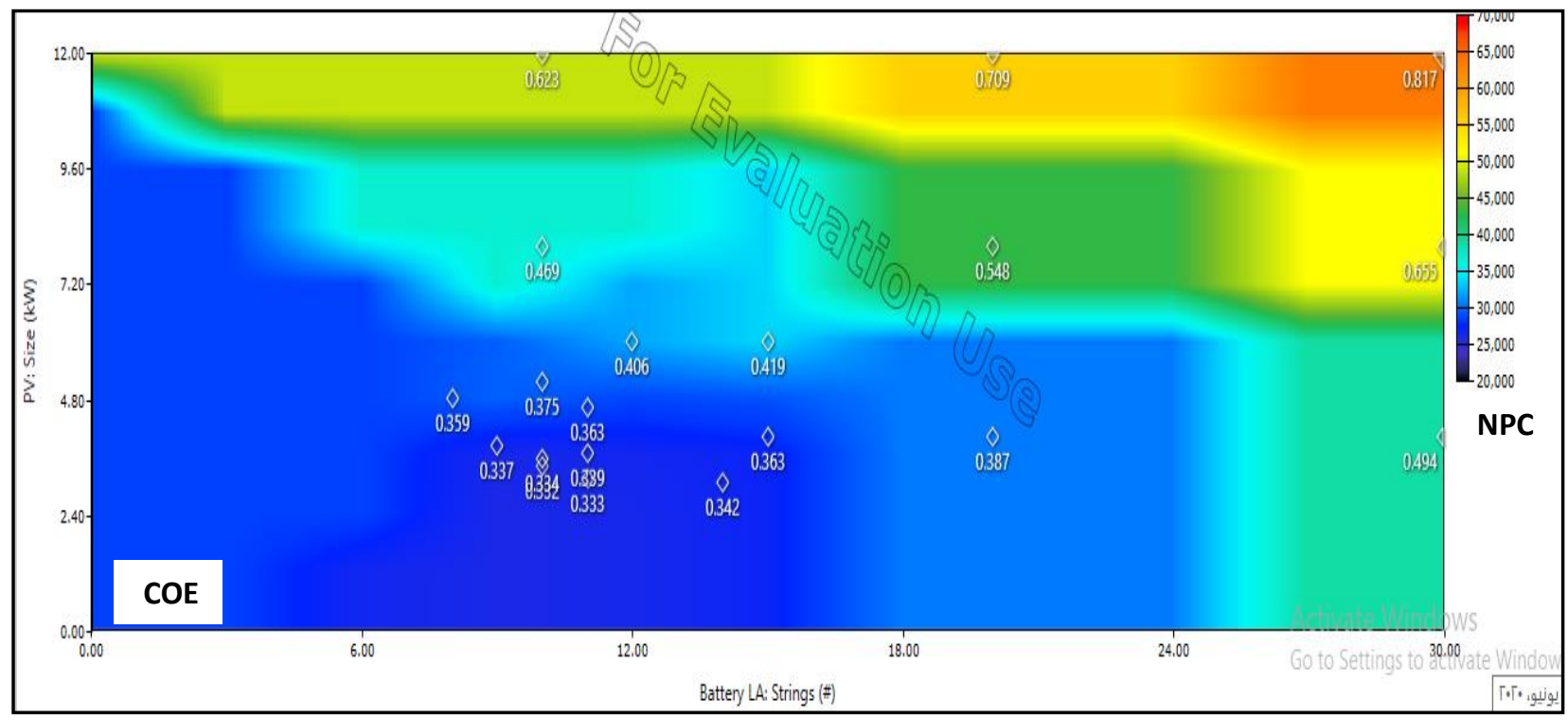

b- PV-battery Off-grid system

Fig.10: Optimization surface Plot for On/Off-Grid Optimum water Pumping Systems

It is clear from figure 10-a, that if PV and converter capacity increase; the net present cost and cost of energy also increase. In figure 10-b, when the battery sizing and PV capacity decreases; the NPC and $\mathrm{COE}$ is also decreases. From table 3 and figures 6:10; PV On-Grid system is the optimum water pumping system for the selected site due to the least net present cost and cost of energy that meets require electric energy of defined load.

\subsection{1: Sensitivity Analysis}

The present study given an insight into the impact of the efficiency of the available power of the optimum PV On-Grid water pumping system in two terms: first, the impact of the minimum renewable fraction on energy costs (COE) and energy sold on the national grid (figure 11). The second term is effect of change in discount rate of Net Present Cost (NPC) and Cost of energy (COE) (figure 12). 


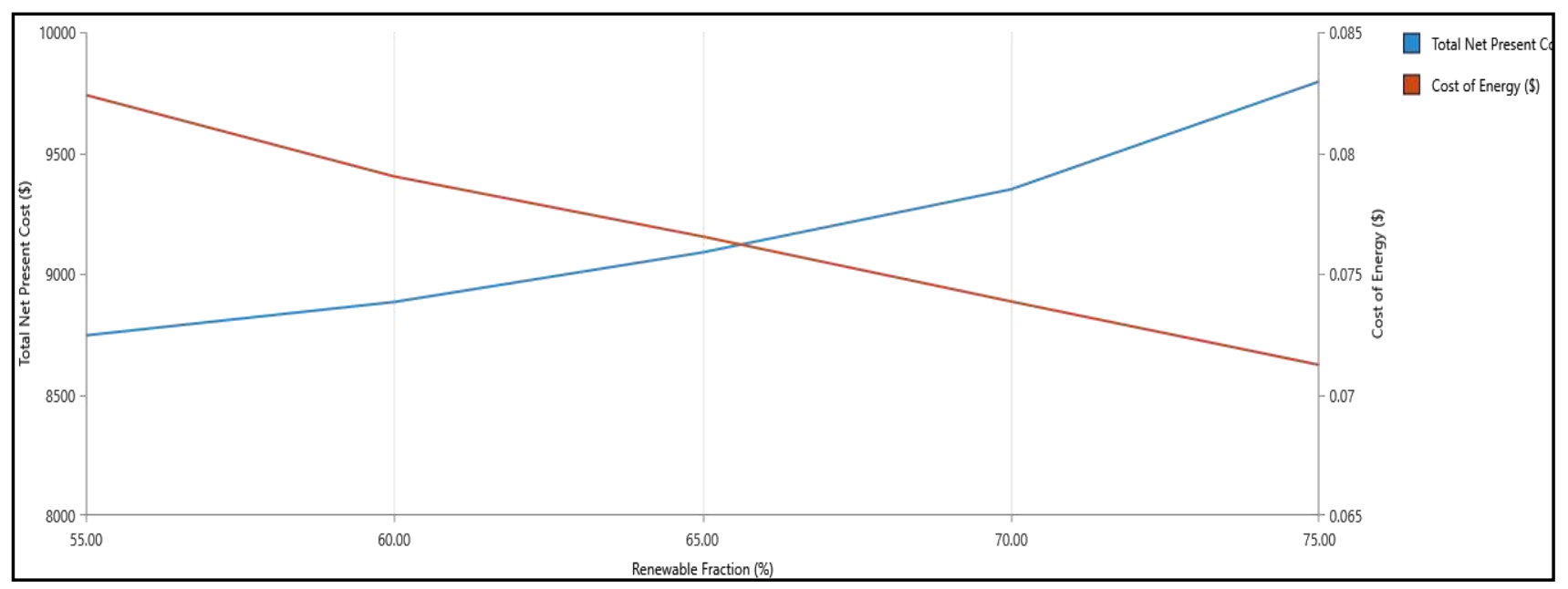

Fig. 11: Cost of Energy vs. Renewable Fraction Percentage of PV On-Grid Optimum Water Pumping System

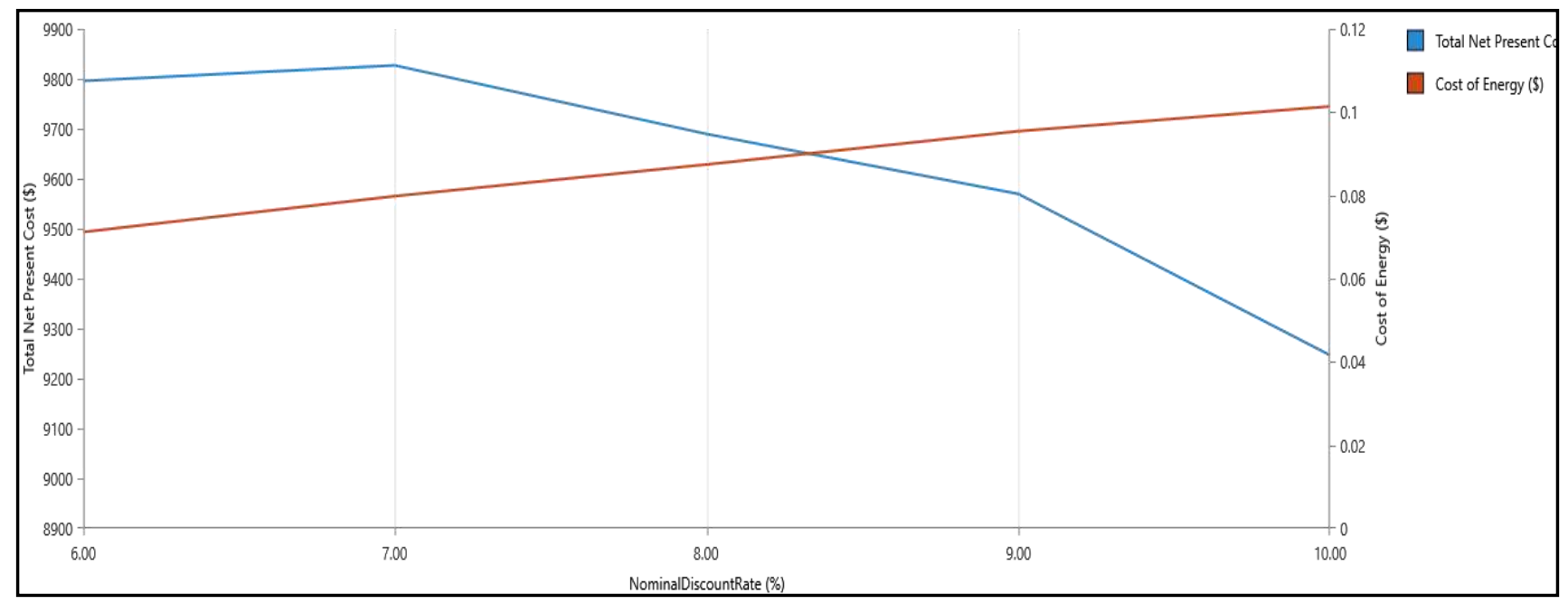

Fig. 12: Net Present Cost vs. Discount Rate Percentage of PV On-Grid Optimum Water Pumping System

Figure 11 shows that $\mathrm{COE}$ is declining as the renewable fraction rises after the increase of sold energy to national grid. From figure 12; it is clear that total net present cost decreases with increase of discount rate while cost of energy increases. (Reason: to calculate the PC the future net cash is divided by $(1+i)^{\mathrm{n}}$, then if I increase NC decrease). Also, sensitivity analysis of change in interest rate (discount rate) is provided for optimum water pumping system of PV-battery off-grid system, diesel system and shown in figure 13 .

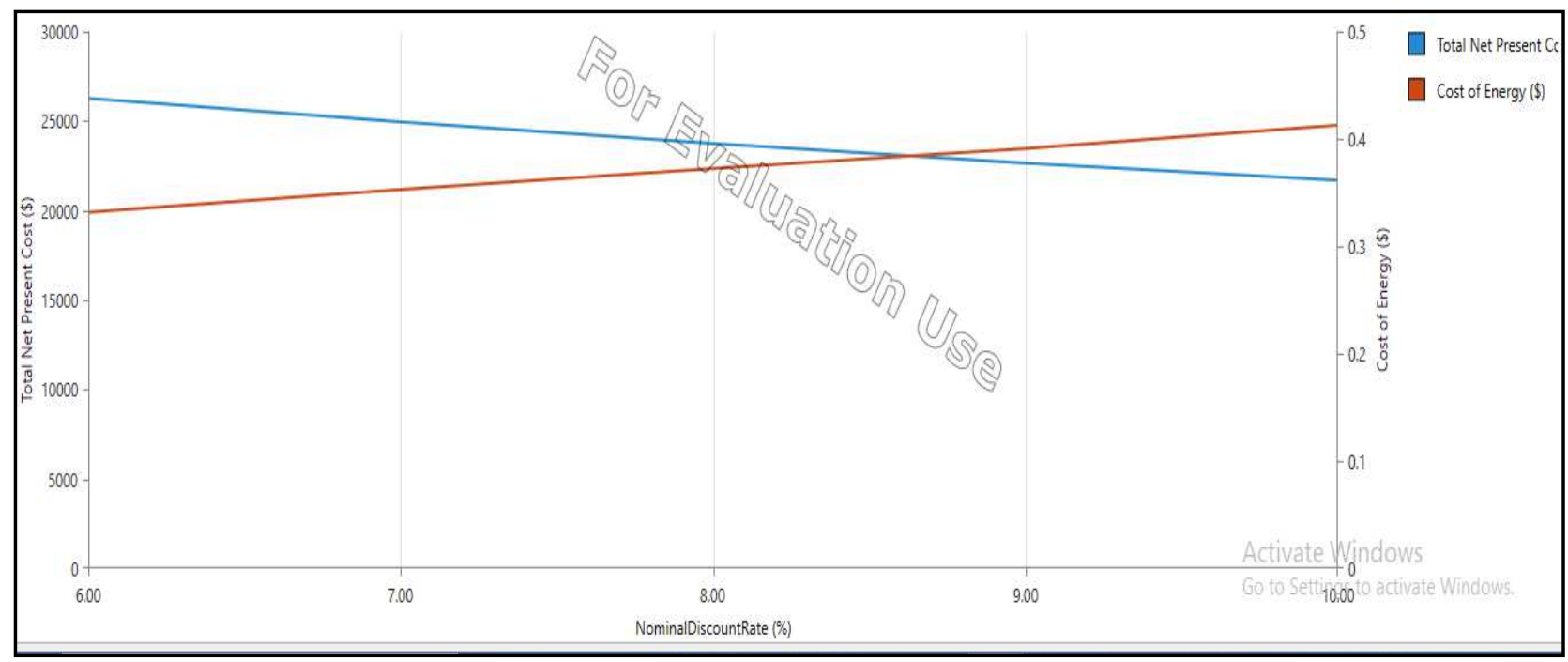

a- PV-Battery Off-grid system 


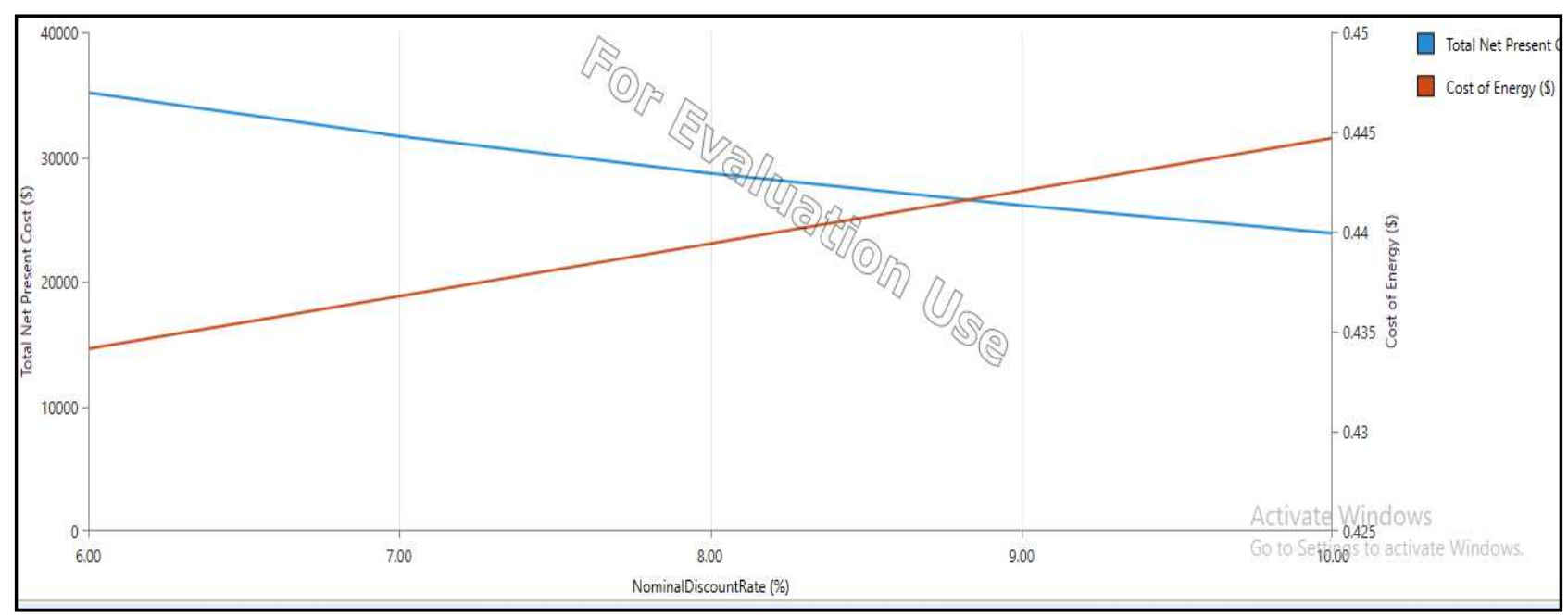

b- Diesel System

Fig.13: NPC \& COE vs. Discount Rate Percentage of PV-Battery/Diesel Water Pumping System

From figure 13; it is found that when discount rate increases, the net present cost and cost of energy also increases for PV-battery off-grid and diesel systems.

\subsection{Water Pump and PV Power Capacity}

A basic power calculation is provided below for the design of a Solar DC Pump for the required capacity.

\subsubsection{Amount of water required}

With an average discharge of $121.14 \mathrm{~m}^{3} / \mathrm{h}$, this system was designed to lift a maximum of $726.85 \mathrm{~m}^{3}$ of water per day (at $12 \mathrm{pm}$ ).

\subsubsection{Total dynamic head (THD) Estimation}

It consists of two factors [35]; TDH=Vertical lift + Frictional losses

Vertical lift $=$ Elevation + standing water level+ Draw down

Frictional losses $=0.5 \%$ of Total vertical lift

From the given specifications in figure 3 of water tank based solar water pumping system; Vertical lift= $12+3 \mathrm{~m}=15 \mathrm{~m}$. Frictional losses $=15 \times 0.0051100=0.0075 \mathrm{~m}$. Then $\mathrm{TDH}=15 \mathrm{~m}+0.0075 \mathrm{~m}=16.0075 \mathrm{~m}$.

\subsubsection{Pump motor size.}

The pump's required hydraulic power is estimated, as seen in equation 3 [13], [29] and efficiency of pump $75 \%$ is also taken into consideration so,

$$
\mathrm{P}_{\text {pump }}=\frac{1000 \times 9.8 \times 121.14 \times 16.0075}{0.75 \times 3600}=7038 \mathrm{~W}=7 \mathrm{~kW}=10 \mathrm{HP}
$$

\subsubsection{PV modules}

During daytime the system is configured to operate for an average of six hours. Usage of the pump $=$ ( $7038 \times 6=42228 \mathrm{Wh} /$ day. To estimate the required PV energy, total watt hours per day are multiplied by 1.3 (system loss) and divided by factor of panel generation (3.2 for Egypt [36]). PV energy required $=(7038 \times 1.3)=54896 \mathrm{Wh} /$ day. Total available Watt power of $\mathrm{PV}=(54896 / 3.2)=17155 \mathrm{~W}=18 \mathrm{~kW}$. Here, we are using $325 \mathrm{~W}$ power modules. Number of PV panels $=(17155 / 325) \approx 52.755=52$ module. The panel selected is 72 cell panels, each string has the number of panels connected in series is four and the number of strings in parallel $=13$ since the bus voltage is $48 \mathrm{~V}$.

\subsubsection{Inverter}

The inverter power is selected as $10 \mathrm{~kW}$ (40 percent considerably larger than the engine size) 


\subsubsection{Battery Storage}

Battery bank essential ampere hour $=(54204 / 48)=879$ Ah for one-day back-up. The rated power of the battery bank is $900 \mathrm{Ah}$, and the nominal voltage $48 \mathrm{~V}$.

\subsubsection{Water Storage Tank}

For maximum water demand of $726 \mathrm{~m}^{3} /$ day, dimensions of storage tank "Storage Size" are $30 \times 22 \times 2.5 \mathrm{~m}$

\section{CONCLUSION}

These diesel-powered pumps are also used for irrigation of the crops and grasslands. Even so, reliability and availability problems can occur where the fuel supply is intermittent and expensive, high maintenance costs and low life expectancy. Technical and economic analysis of the water pumping for irrigation and human needs of $443 \mathrm{~kW}$ peak using solar energy and diesel are discussed for two pumping systems of the agriculture remote location in El Gharaq, Etsa town, Fayoum city, Egypt. The performance analysis demonstrates solar water pumping technology, optimum sizing techniques, economic analysis and environmental aspects that were carried out worldwide. The system approach investigates: diesel system, PV/battery off-grid system and comparing with extension grid of PV/Grid system. The proposed system optimization approach was performed using HOMER 3.13.8 software in terms of minimum NPC, COE and $\mathrm{CO}_{2}$ saving. The study's key conclusions are as follows:

- Technology of Solar water pumping is a financially efficient and effective alternative to the electric and diesel water pumps for agricultural crop irrigation.

- Solar water pumping would be another feasible zone for sources and institutions of urban, rural and community water, but is still not commonly used. Particular attention also needs to be paid to rural, inaccessible areas without grid electricity. These industries continue to rely on traditional pumping systems based on electricity or diesel, resulting in higher, rising costs for customers.

- The optimal configurations of this proposed system are $2.57 \mathrm{~kW}$ of PV and $2.11 \mathrm{~kW}$ converter of ongrid system while $3.83 \mathrm{~kW}$ PV and $1.71 \mathrm{~kW}$ converter and 10 units of $12 \mathrm{~V}$ batteries for PV/battery offgrid system and $3.10 \mathrm{~kW}$ PV for diesel system.

- Net present cost of solar water pumping system in on-grid mode is three times of the PV-battery off-grid system and four times of convention diesel system net present cost.

- The cost of energy of solar water pumping system is $0.07 \$ / \mathrm{kWh}$ while $0.332 \$ / \mathrm{kWh}$ for PV-battery and $0.434 \$ / \mathrm{kWh}$ for diesel system. The system with the abovementioned configuration pumps an average hourly water volume of approximately $121.4 \mathrm{~m}^{3}$ over one year with a unit of $0.05 \mathrm{cent} / \mathrm{m}^{3}$.

- For solar water pumping systems, the investment payback is found to be 4-6 years.

- Moreover, from an environmental point of view, the results showed that $\mathrm{CO}_{2}$ output for the on-grid solar water pumping system during the project's lifetime is six times lower than that for the convention diesel system.

- Through sensitivity analysis; energy costs rise by increasing the water storage tank's maximum capacity. Also, when discount rate is increasing; the NPC and COE are also increasing.

- The Pumping Power capacity is also estimated for this water pumping system and it is found around 7 $\mathrm{kW}(10 \mathrm{HP})$.

- The results indicate that extension PV on-grid pumping system is the optimum solution for the selected site.

The research applies on importance in view of the ever-increasing cost of diesel and the shortage of grid electricity for irrigation, as it demonstrates that photovoltaic water pumping systems can be used effectively in developing countries, in particular to improve agricultural production, drinking supplies, surface irrigation such as greenhouse, pasture and drip irrigation, taking into account the fairness overall the 25 years of warranty period. 


\section{Declarations}

\section{Availability of Data and Materials}

The data that support the findings of this study are available from the corresponding author upon reasonable request.

\section{Competing Interests}

This paper is more interesting for new technology of solar water pumping. The author declare no conflict of interest.

\section{Funding}

Not applicable

\section{Authors' contributions}

The corresponding author contribution is $100 \%$ percentage. No other authors participate in this paper.

\section{Acknowledgements}

Not applicable

\section{REFERENCES}

[1] S. Rehman and A. Z. Sahin, "Performance comparison of diesel and solar photovoltaic power systems for water pumping in Saudi Arabia," Int. J. Green Energy, vol. 12, no. 7, pp. 702-713, 2015, doi: 10.1080/15435075.2014.884498.

[2] A. Allouhi et al., "PV water pumping systems for domestic uses in remote areas: Sizing process, simulation and economic evaluation," Renew. Energy, vol. 132, pp. 798-812, 2019, doi: 10.1016/j.renene.2018.08.019.

[3] D. H. Muhsen, T. Khatib, and H. T. Haider, "A feasibility and load sensitivity analysis of photovoltaic water pumping system with battery and diesel generator," Energy Convers. Manag., vol. 148, pp. 287304, 2017, doi: 10.1016/j.enconman.2017.06.007.

[4] M. N. I. Sarkar and H. R. Ghosh, "Techno-economic analysis and challenges of solar powered pumps dissemination in Bangladesh," Sustain. Energy Technol. Assessments, vol. 20, pp. 33-46, 2017, doi: 10.1016/j.seta.2017.02.013.

[5] H. Rezk, M. A. Abdelkareem, and C. Ghenai, "Performance evaluation and optimal design of standalone solar PV-battery system for irrigation in isolated regions: A case study in Al Minya (Egypt)," Sustain. Energy Technol. Assessments, vol. 36, no. May, p. 100556, 2019, doi: 10.1016/j.seta.2019.100556.

[6] M. Aliyu, G. Hassan, S. A. Said, M. U. Siddiqui, A. T. Alawami, and I. M. Elamin, "A review of solar-powered water pumping systems," Renew. Sustain. Energy Rev., vol. 87, no. August 2017, pp. 61-76, 2018, doi: 10.1016/j.rser.2018.02.010.

[7] M. Á. P. Picazo, J. M. Juárez, and D. García-Márquez, "Energy consumption optimization in irrigation networks supplied by a standalone direct pumping photovoltaic system," Sustain., vol. 10, no. 11, 2018, doi: 10.3390/su10114203.

[8] S. S. Chandel, M. Nagaraju Naik, and R. Chandel, "Review of solar photovoltaic water pumping system technology for irrigation and community drinking water supplies," Renew. Sustain. Energy Rev., vol. 49, pp. 1084-1099, 2015, doi: 10.1016/j.rser.2015.04.083.

[9] S. Laamari, W. Zghal, and H. Kchaou, "Optimization of hybrid system (wind-solar energy) for pumping water," Int. J. Eng. Sci. Technol., vol. 7, no. 2, p. 11, 2016, doi: 10.4314/ijest.v7i2.2.

[10]F. J. Chueco-Fernández and Á. A. Bayod-Rújula, "Power supply for pumping systems in northern Chile: Photovoltaics as alternative to grid extension and diesel engines," Energy, vol. 35, no. 7, pp. 2909-2921, 2010, doi: 10.1016/j.energy.2010.03.022.

[11]A. A. Setiawan, D. H. Purwanto, D. S. Pamuji, and N. Huda, "Development of a solar water pumping system in karsts rural area tepus, gunungkidul through student community services," Energy Procedia, vol. 47, no. V, pp. 7-14, 2014, doi: 10.1016/j.egypro.2014.01.190. 
[12]E. Mahmoud and H. el Nather, "Renewable energy and sustainable developments in Egypt: Photovoltaic water pumping in remote areas," Appl. Energy, vol. 74, no. 1-2, pp. 141-147, 2003, doi: 10.1016/S0306-2619(02)00140-X.

[13] A. Nikzad, M. Chahartaghi, and M. H. Ahmadi, "Technical, economic, and environmental modeling of solar water pump for irrigation of rice in Mazandaran province in Iran: A case study," J. Clean. Prod., vol. 239, p. 118007, 2019, doi: 10.1016/j.jclepro.2019.118007.

[14]I. Yahyaoui, A. Atieh, A. Serna, and F. Tadeo, "Sensitivity analysis for photovoltaic water pumping systems: Energetic and economic studies," Energy Convers. Manag., vol. 135, pp. 402-415, 2017, doi: 10.1016/j.enconman.2016.12.096.

[15]A. Parvaresh Rizi, A. Ashrafzadeh, and A. Ramezani, "A financial comparative study of solar and regular irrigation pumps: Case studies in eastern and southern Iran," Renew. Energy, vol. 138, pp. 1096-1103, 2019, doi: 10.1016/j.renene.2019.02.026.

[16]R. Sharma, S. Sharma, and S. Tiwari, "Design optimization of solar PV water pumping system," Mater. Today Proc., vol. 21, pp. 1673-1679, 2019, doi: 10.1016/j.matpr.2019.11.322.

[17] A. Boutelhig, A. Hadjarab, and Y. Bakelli, "Comparison study to select an optimum photovoltaic pumping system (PVPS) configuration upon experimental performances data of two different dc pumps tested at Ghardaïa site," Energy Procedia, vol. 6, pp. 769-776, 2011, doi: 10.1016/j.egypro.2011.05.087.

[18] M.BenghanemK.O.DaffallahA.A.JoraidS.N.AlamriA.Jaber, "Performances of solar water pumping system using helical pump for a deep well: A case study for Madinah, Saudi Arabia," Energy Convers. Manag., vol. 65, pp. 50-56, 2013.

[19] T. H. Hamidat, B Benyoucef, "Small-scale irrigation with photovoltaic water pumping system in Sahara regions," Renew. Energy, vol. 28, no. 7, pp. 1081-1096, 2003.

[20]P. K. S. Rathore, S. S. Das, and D. S. Chauhan, "Perspectives of solar photovoltaic water pumping for irrigation in India," Energy Strateg. Rev., vol. 22, no. November, pp. 385-395, 2018, doi: 10.1016/j.esr.2018.10.009.

[21] A. Mérida García, J. Gallagher, A. McNabola, E. Camacho Poyato, P. Montesinos Barrios, and J. A. Rodríguez Díaz, "Comparing the environmental and economic impacts of on- or off-grid solar photovoltaics with traditional energy sources for rural irrigation systems," Renew. Energy, vol. 140, pp. 895-904, 2019, doi: 10.1016/j.renene.2019.03.122.

[22]E. R. Shouman, E. T. El Shenawy, and M. A. Badr, "Economics analysis of diesel and solar water pumping with case study water pumping for irrigation in Egypt," Int. J. Appl. Eng. Res., vol. 11, no. 2, pp. 950-954, 2016.

[23]"Site Geography Map."

[24]H. Rezk and I. T. and A. Raupov, "Experimental implementation of meteorological data and photovoltaic solar radiation monitoring system,” Int. Trans. Electr. ENERGY Syst., vol. 25, p. :3573$3585,2015$.

[25] M. Tolba, H. Rezk, A. A. Z. Diab, and M. Al-Dhaifallah, "A novel robust methodology based Salp Swarm Algorithm for allocation and capacity of renewable distributed generators on distribution grids,” Energies, vol. 11, no. 10, 2018, doi: 10.3390/en11102556.

[26]"National Aeronautics and Space Administration, NASA." [Online]. Available: https://power.larc.nasa.gov/data-access-viewer/.

[27]H. Rezk, "A comprehensive sizing methodology for stand-alone battery-less photovoltaic water pumping system under the Egyptian climate," J. Cogent Eng., vol. 3, no. 1, 2016.

[28]F. Diab, H. Lan, L. Zhang, and S. Ali, "An environmentally-friendly tourist village in Egypt based on a hybrid renewable energy system-Part one: What is the optimum city?," Energies, vol. 8, no. 7, pp. 6926-6944, 2015, doi: 10.3390/en8076926.

[29]L. Aiswarya, K. Arunadevi, R. Lalitha, and S. Vallalkannan, "Performance Evaluation of Solar Photovoltaic Water Pumping System,” Int. J. Curr. Microbiol. Appl. Sci., vol. 7, no. 12, pp. 26272632, 2018, doi: 10.20546/ijcmas.2018.712.298. 
[30]L. C. K. D.EppingercStevenDubowsky, "On the feasibility of solar-powered irrigation," Renew. Sustain. Energy Rev., vol. 14, pp. 2669-2682, 2010.

[31]C. Sinton, R. Butler, and R. Winnett, "Guide to solar-powered water pumping systems in New York State," pp. 5-29, 2013.

[32] T. Lambert, P. Gilman, and P. Lilienthal, "Micropower System Modeling with Homer," Integr. Altern. Sources Energy, pp. 379-418, 2006, doi: 10.1002/0471755621.ch15.

[33]E. E. H. C. \& E. E. T. C. Ministry of Electricity and Renewable Energy, "Renewable Energy Electricity Cost," 2019. .

[34] W. Turbine, S. Pv, S. Battery, S. E. Working, M. Products, and W. Site, "Addis Ababa Institute of Technology School of Graduate Studies Energy Center Simulation and Optimization of Wind Turbine , Solar PV , Storage Battery and Diesel Generator Hybrid Power System for a Cluster of Micro and Small Enterprises Working on Wood and," no. February, 2013.

[35]P. Badari Narayana, P. Motepalli, B. R. Sanjeeva Reddy, and S. Dubey, "Design \& simulation of solar DC pump in simulink," 2013 Int. Conf. Energy Effic. Technol. Sustain. ICEETS 2013, no. April, pp. 429-431, 2013, doi: 10.1109/ICEETS.2013.6533421.

[36] "Daily solar irradiance for a given month based on monthly average hourly radiations," pp. 4-5, 2017. 


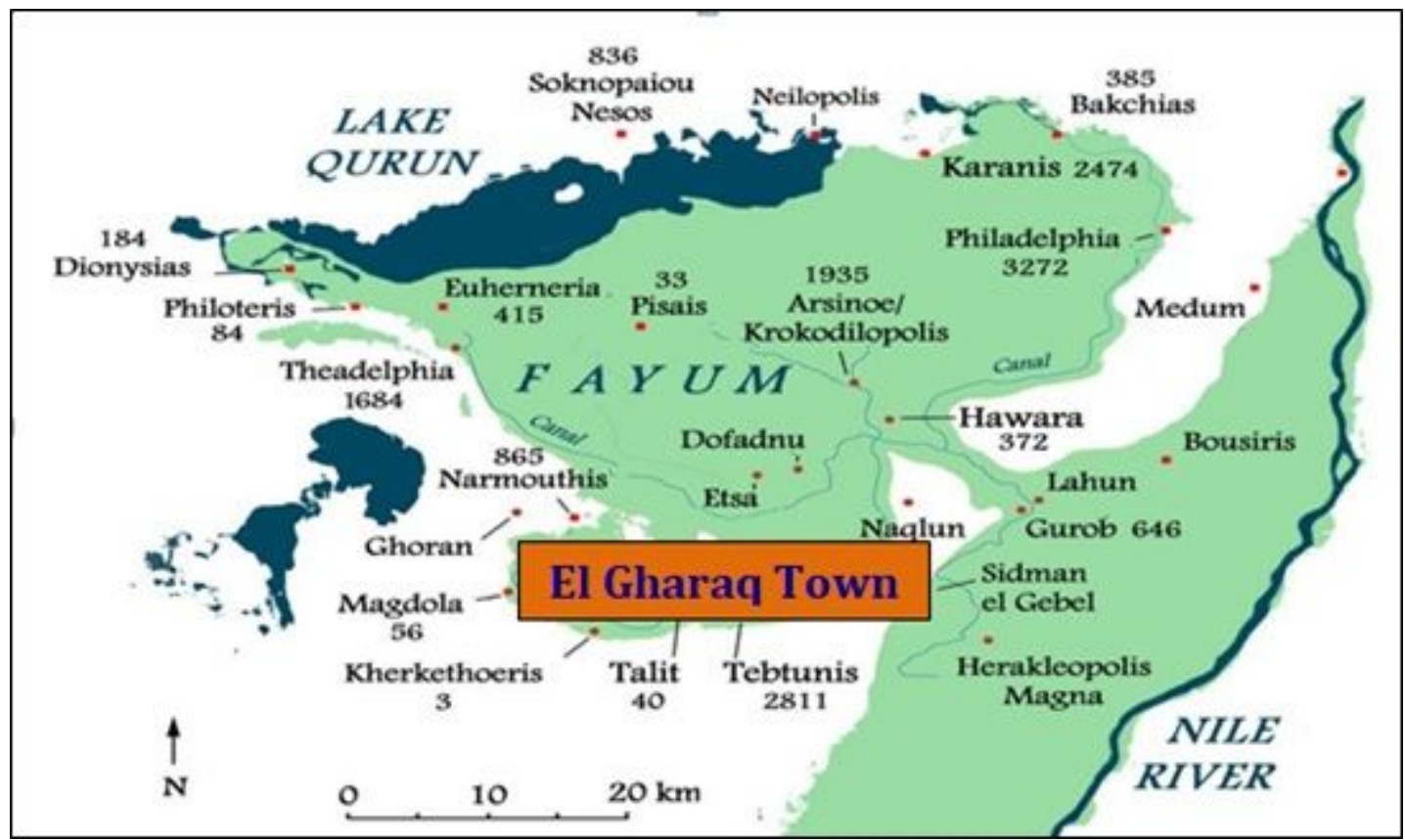

\section{Figure 1}

Geographical location for El Gharaq Town, Etsa Region, Fayoum City, Egypt [23] Note: The designations employed and the presentation of the material on this map do not imply the expression of any opinion whatsoever on the part of Research Square concerning the legal status of any country, territory, city or area or of its authorities, or concerning the delimitation of its frontiers or boundaries. This map has been provided by the authors.

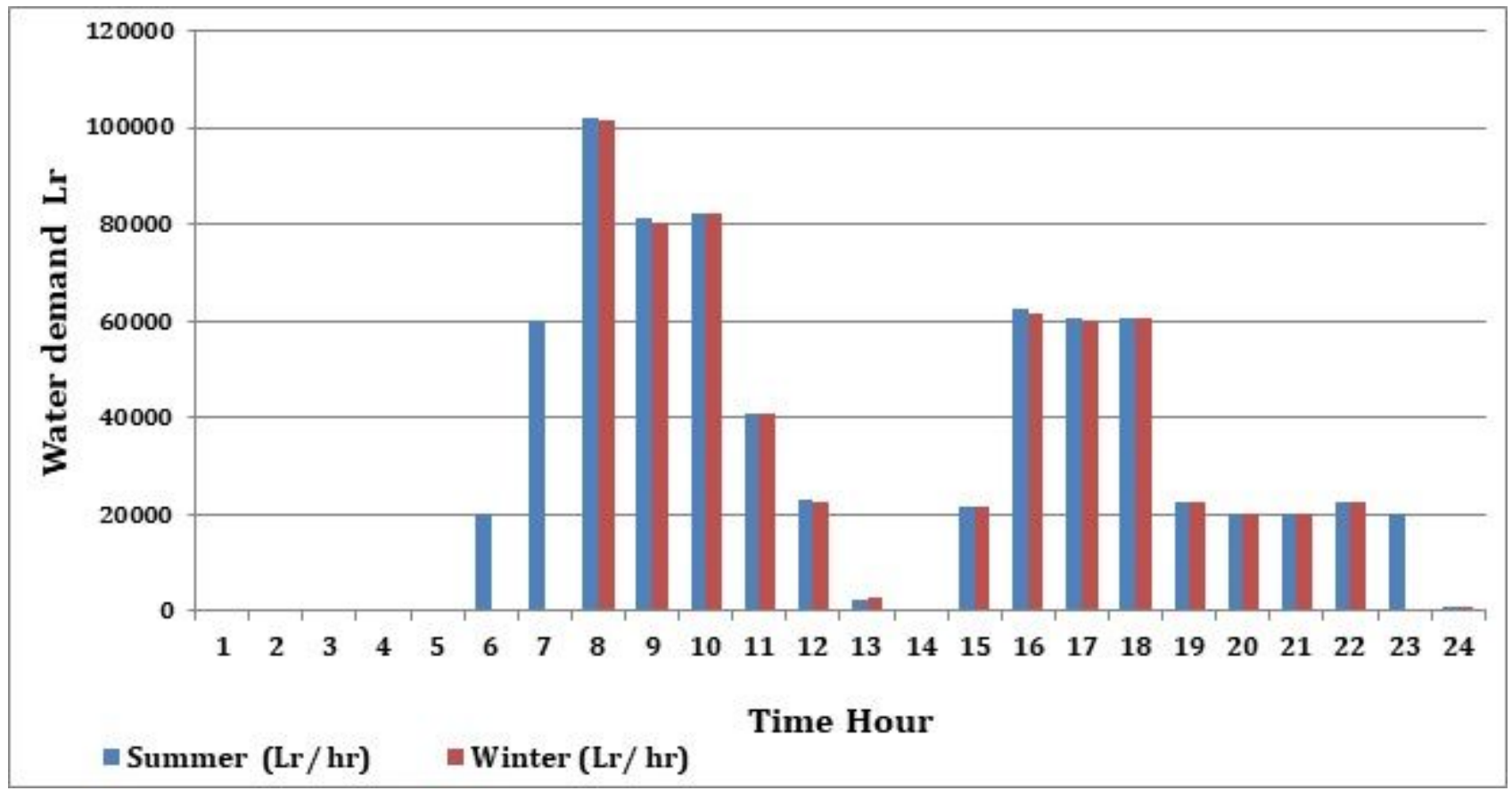

Figure 2 


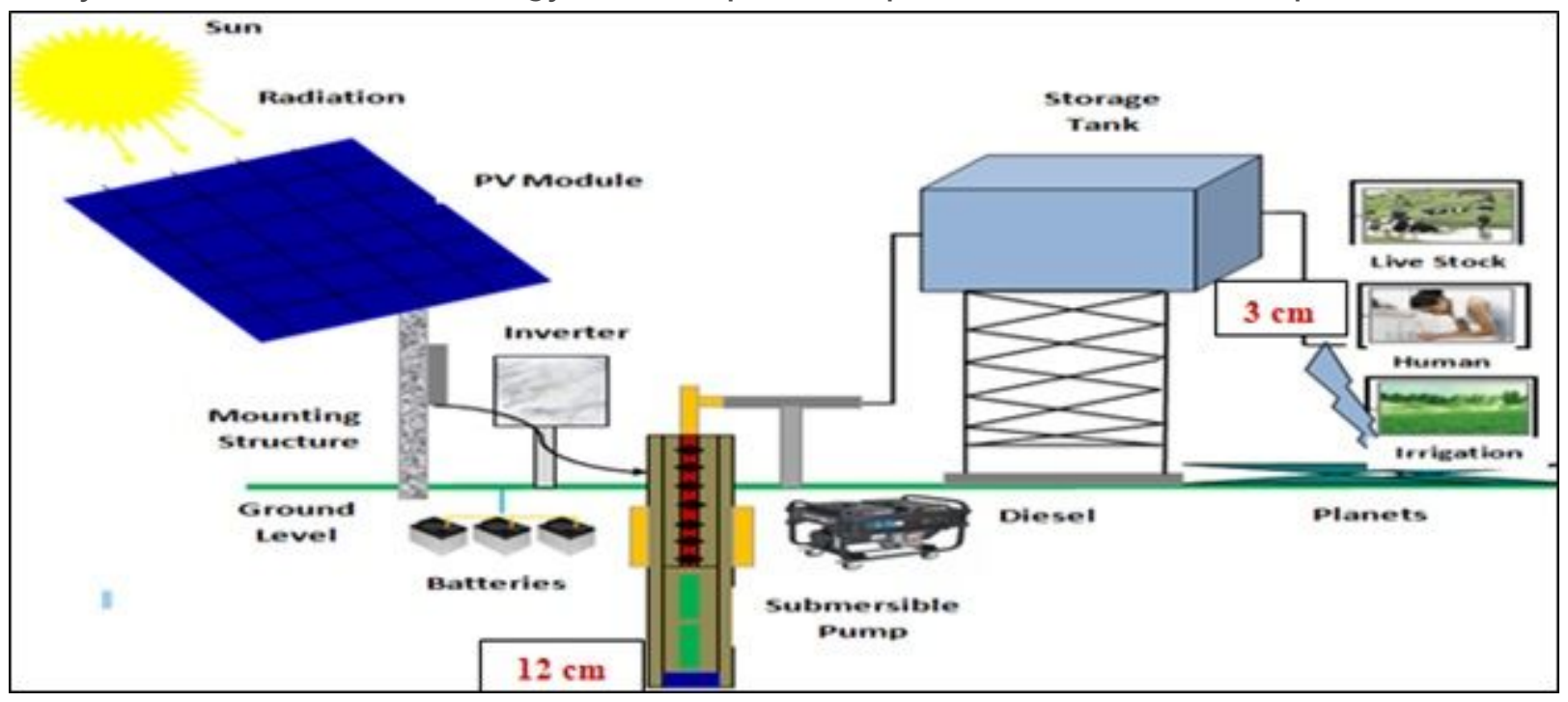

Figure 3

Proposed System Description Components

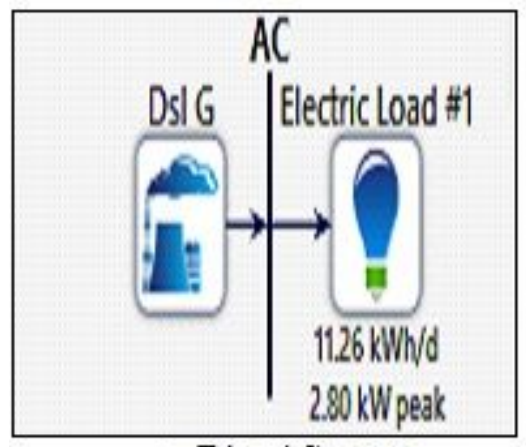

a. Die se1 System

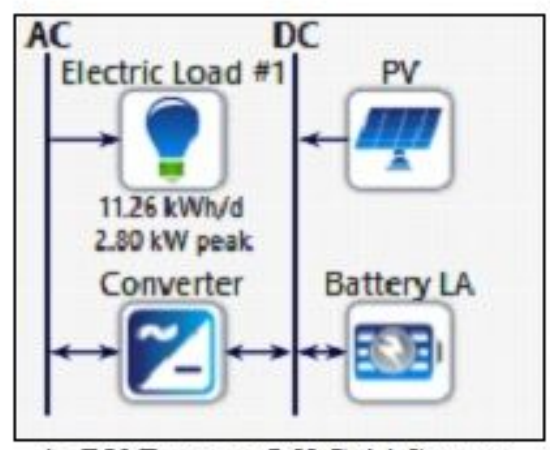

b. PV/B attery Off-Grid System

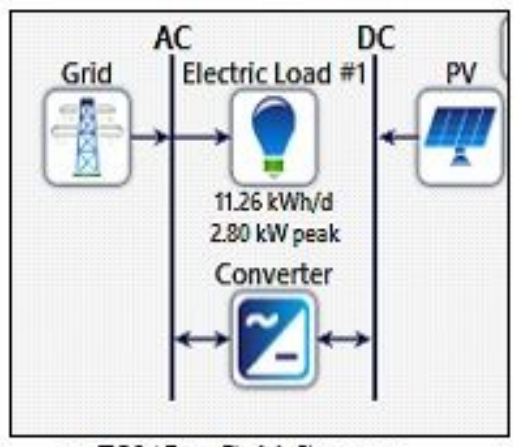

c. PV/On-Grid System

Figure 4

On/Off-Grid Solar Power Pumping System Scheme Implemented In HOMER 


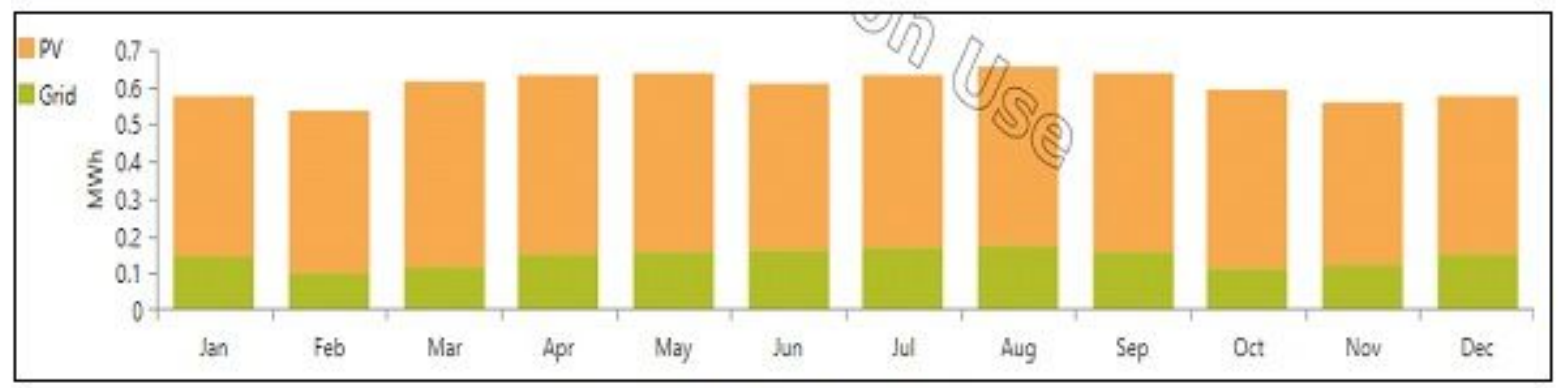

a. PV On-Grid System

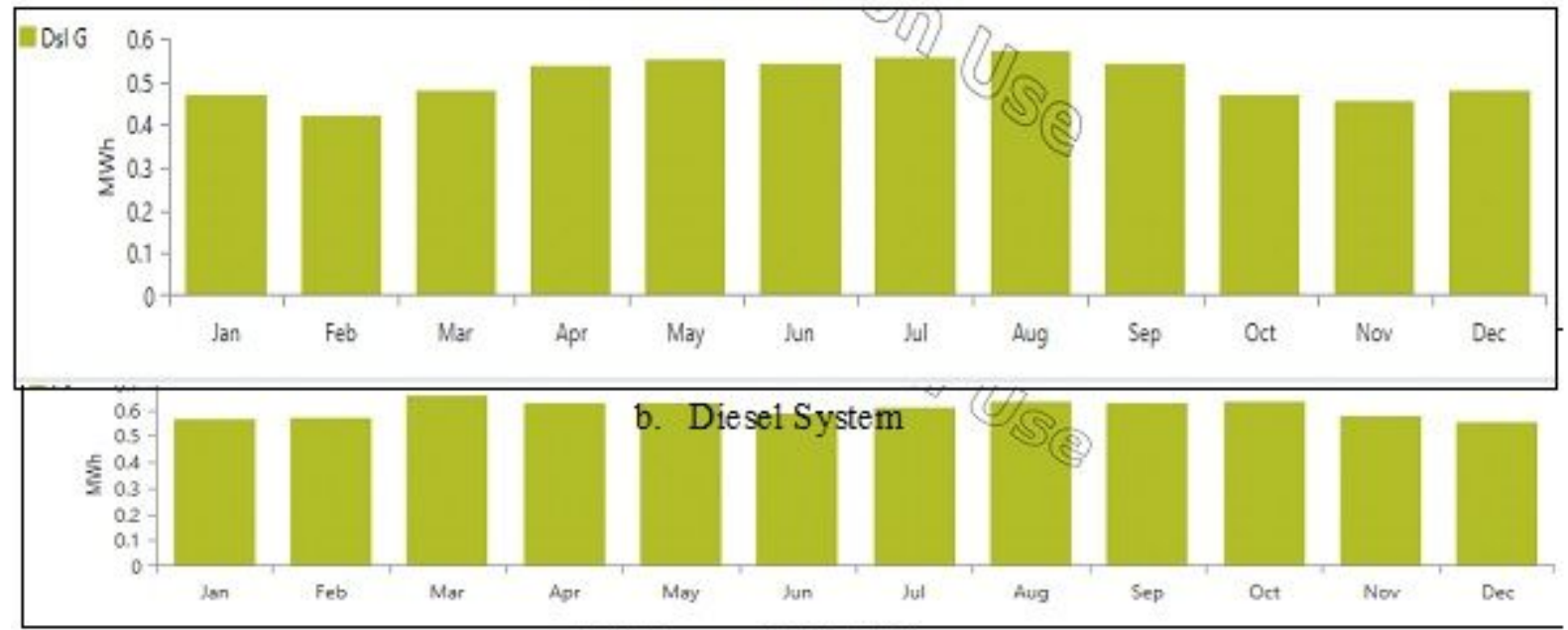

c. PV/B attery Off-Grid System

Figure 5

Monthly Electric Production of the Optimum Water Pumping System

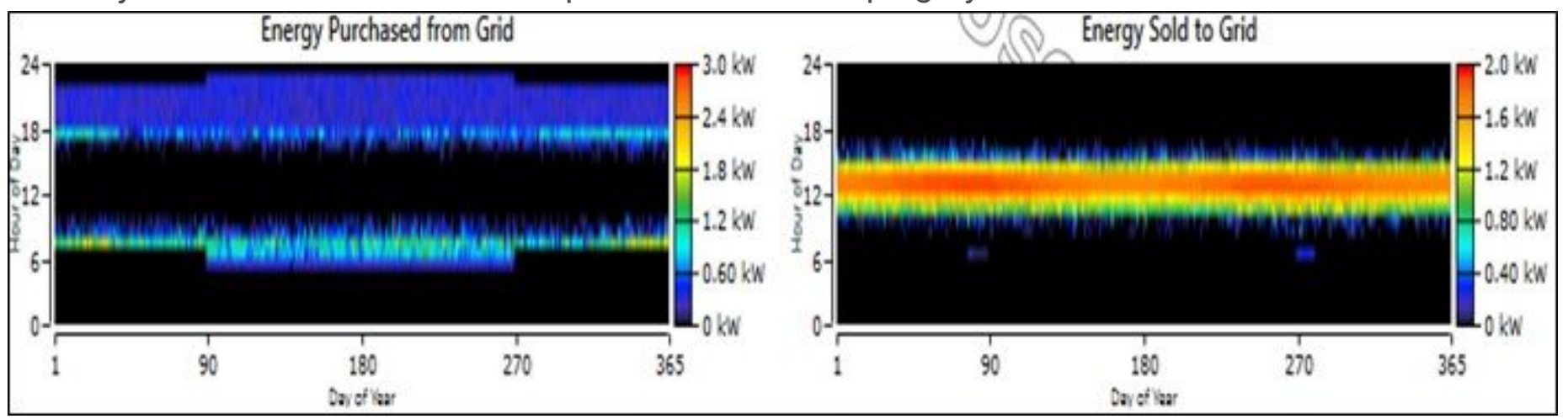

Figure 6

Hourly Electric Energy Purchase/Sold kWh of National Grid whole the year 

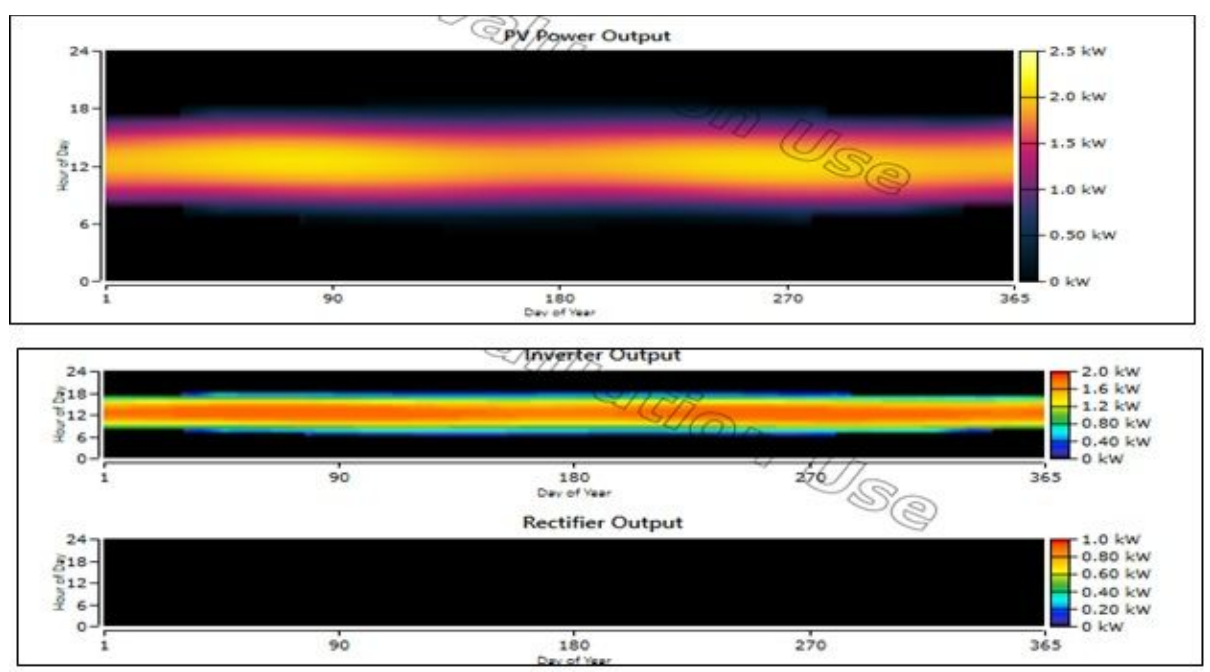

a- On-grid System
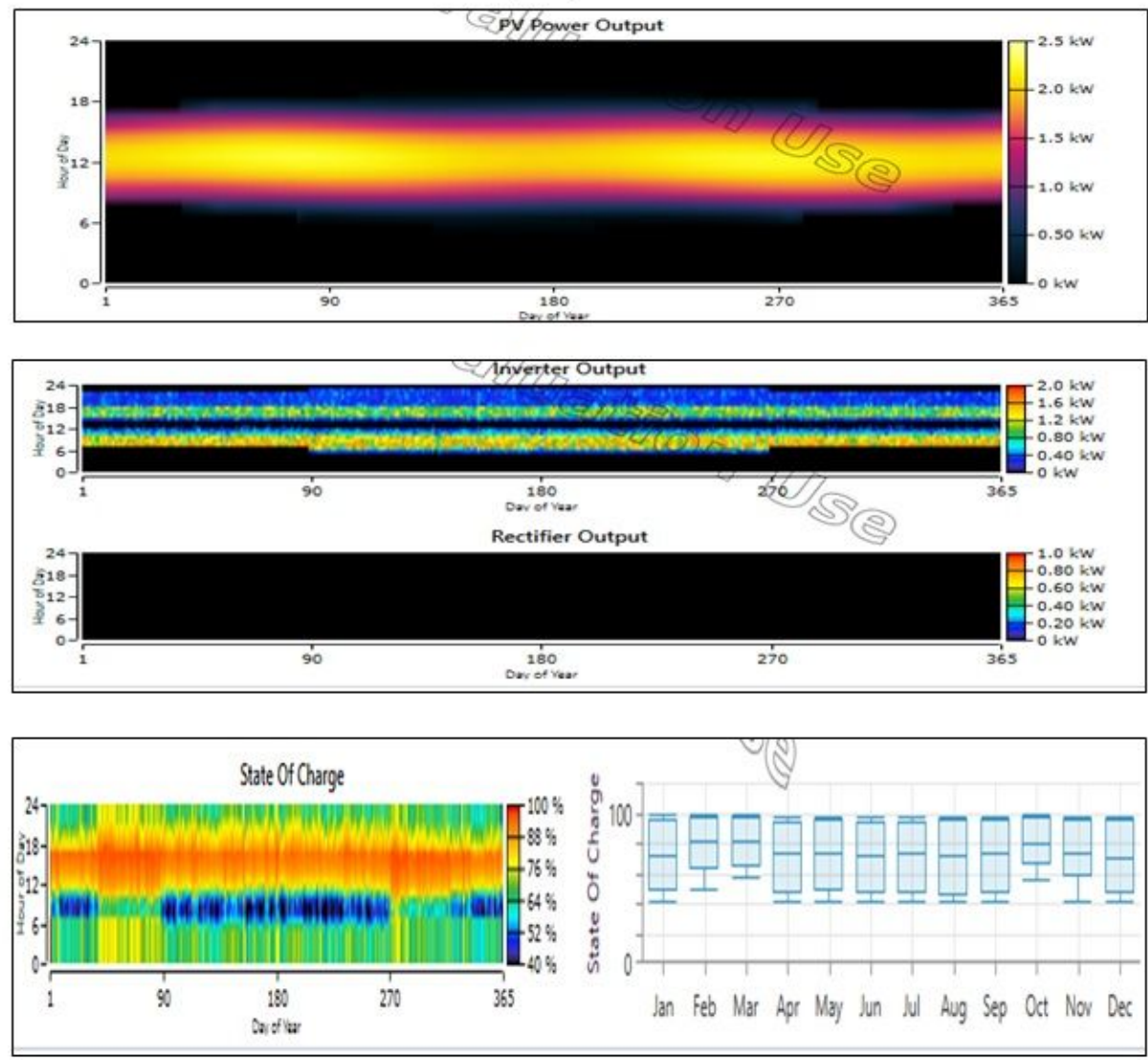

a- PV-B attery Off-grid System

Figure 7

Hourly PV/inverter power Output of On/Off - Grid System Water Pumping System 


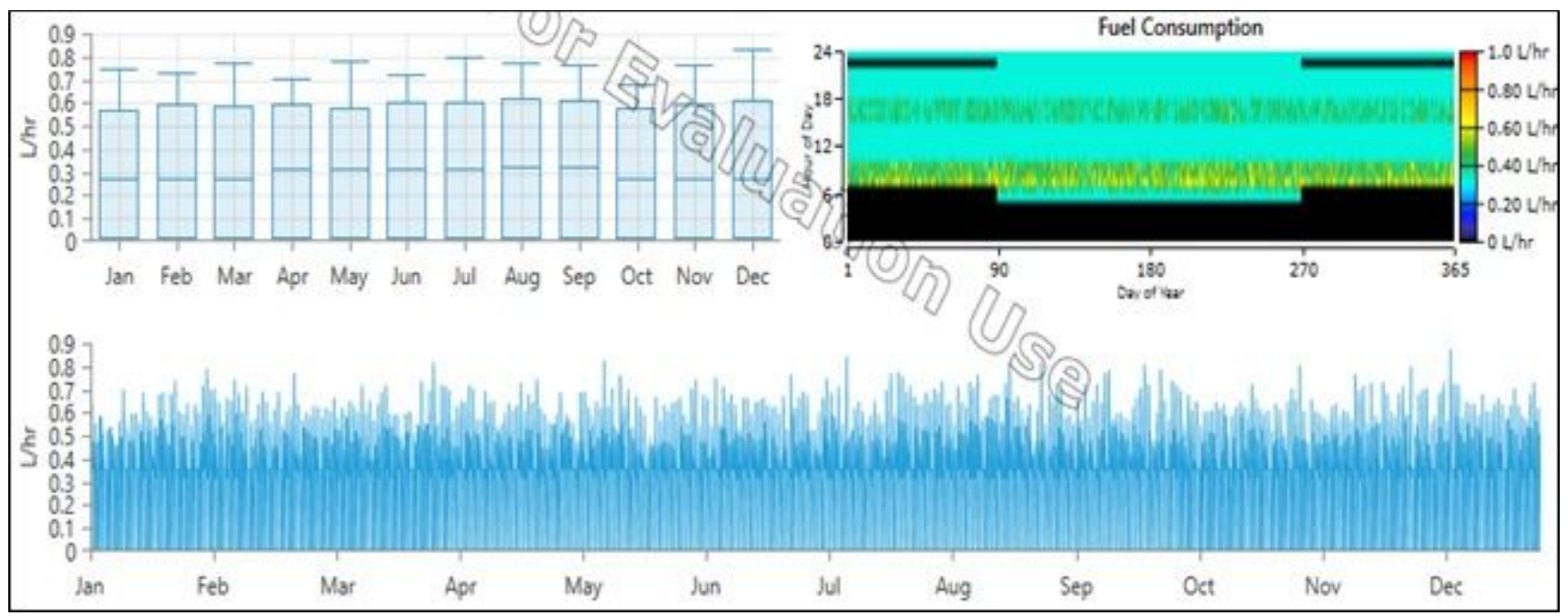

\section{Figure 8}

Hourly Fuel Consumption Whole the Year of diesel Water Pumping System

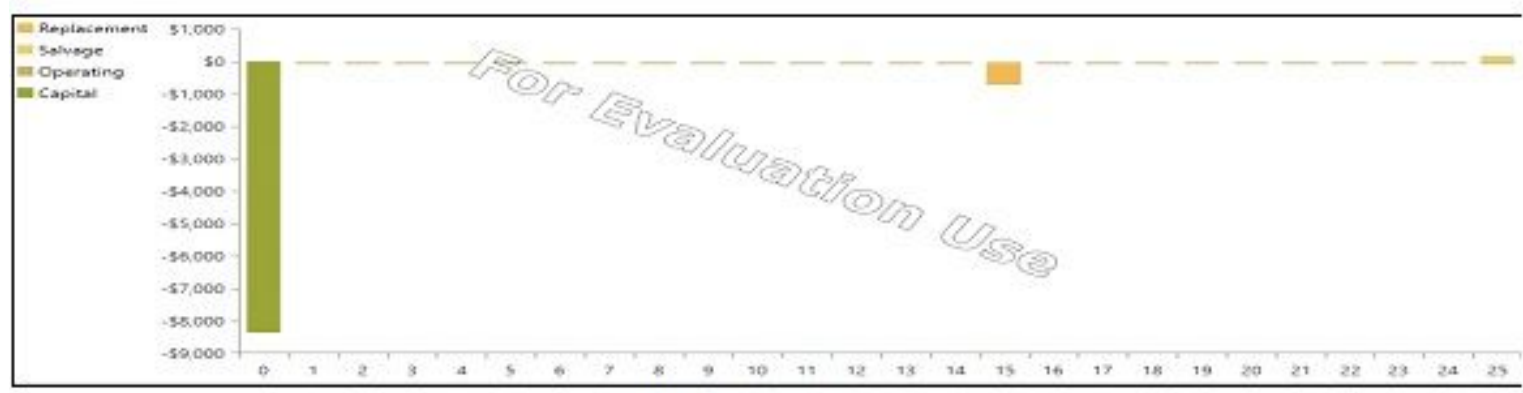

a. PV On-Grid System

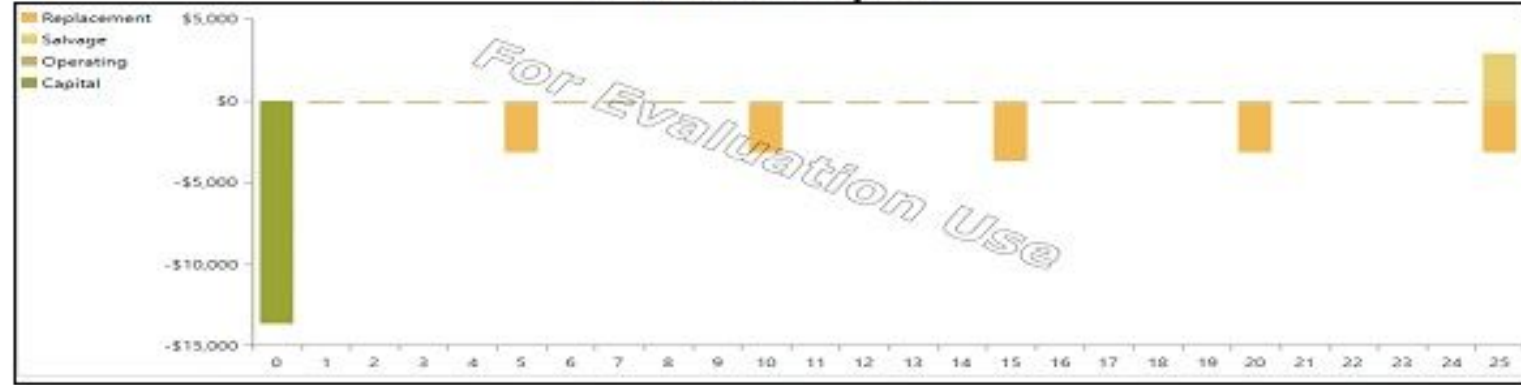

b. PV/B attery Off-Grid System

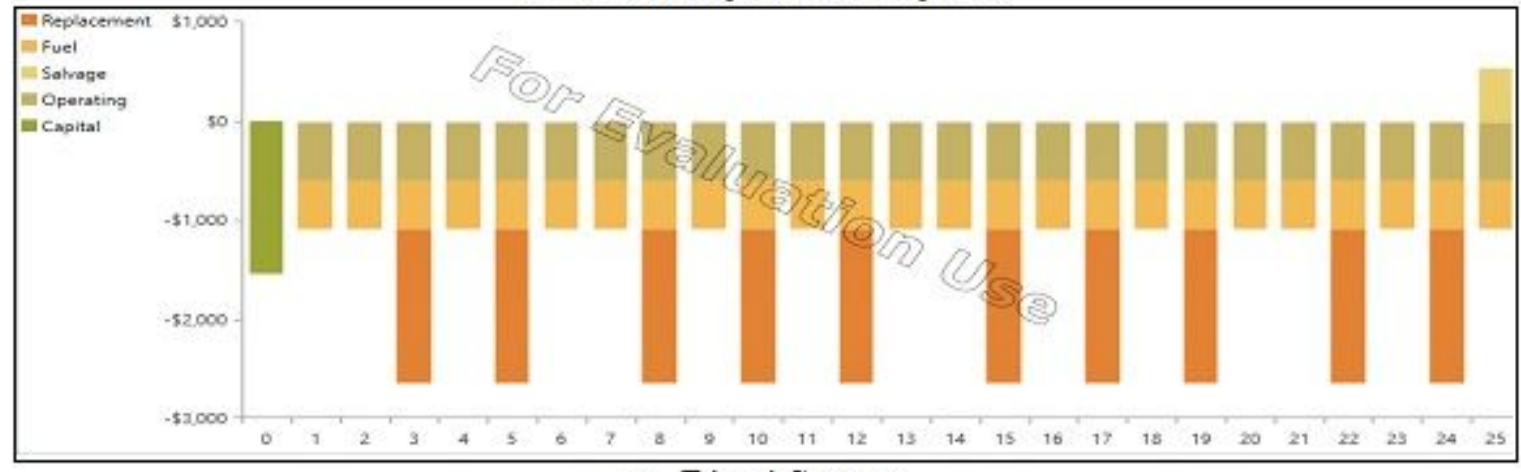

c. Diesel System 
Cash flow Diagram of the Optimum Water Pumping System

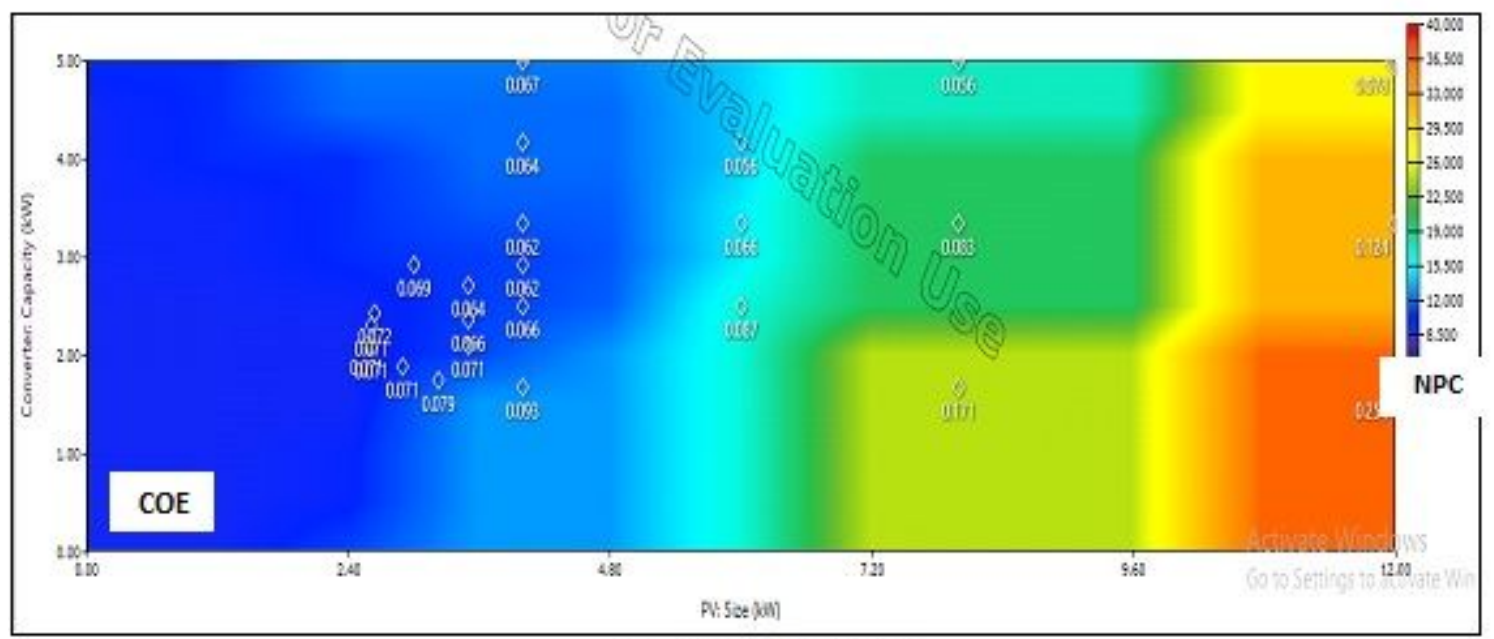

a- On-grid system

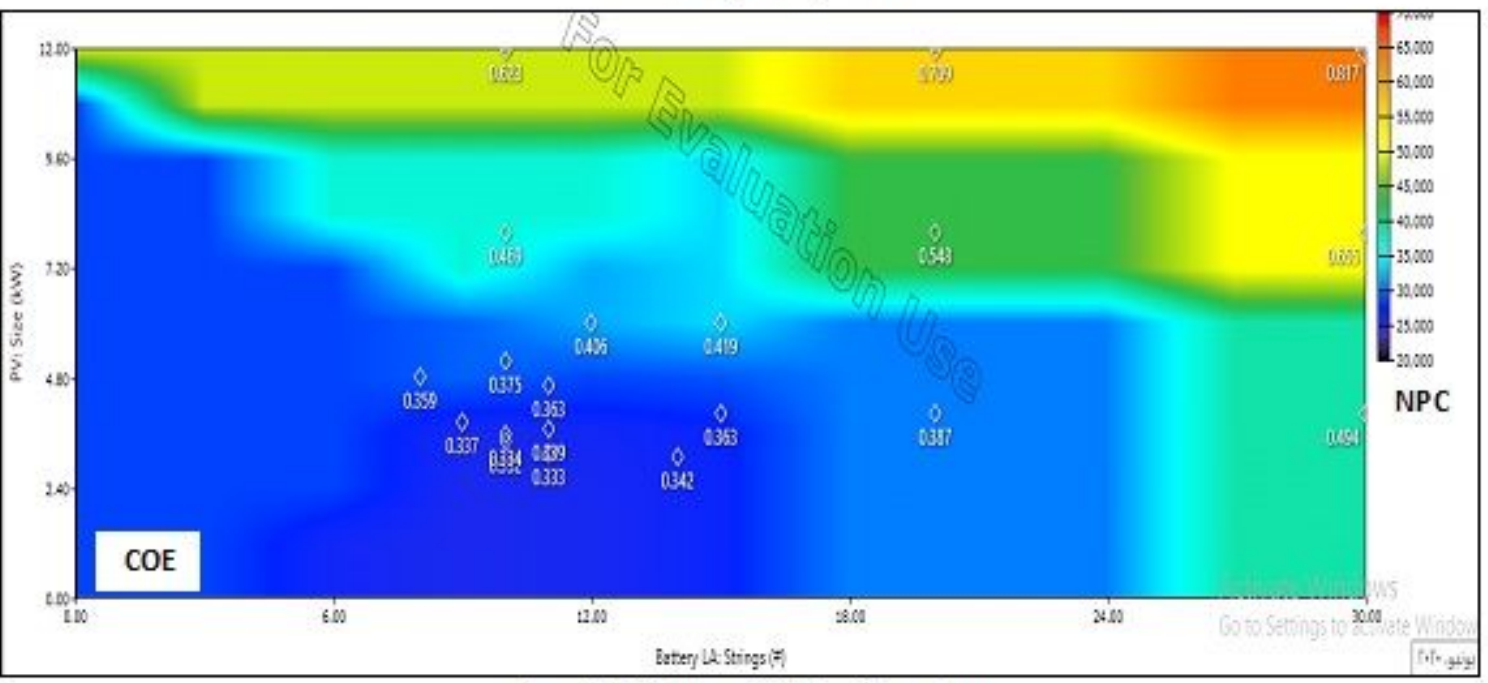

b- PV-battery Off-grid system

Figure 10

Optimization surface Plot for On/Off-Grid Optimum water Pumping Systems

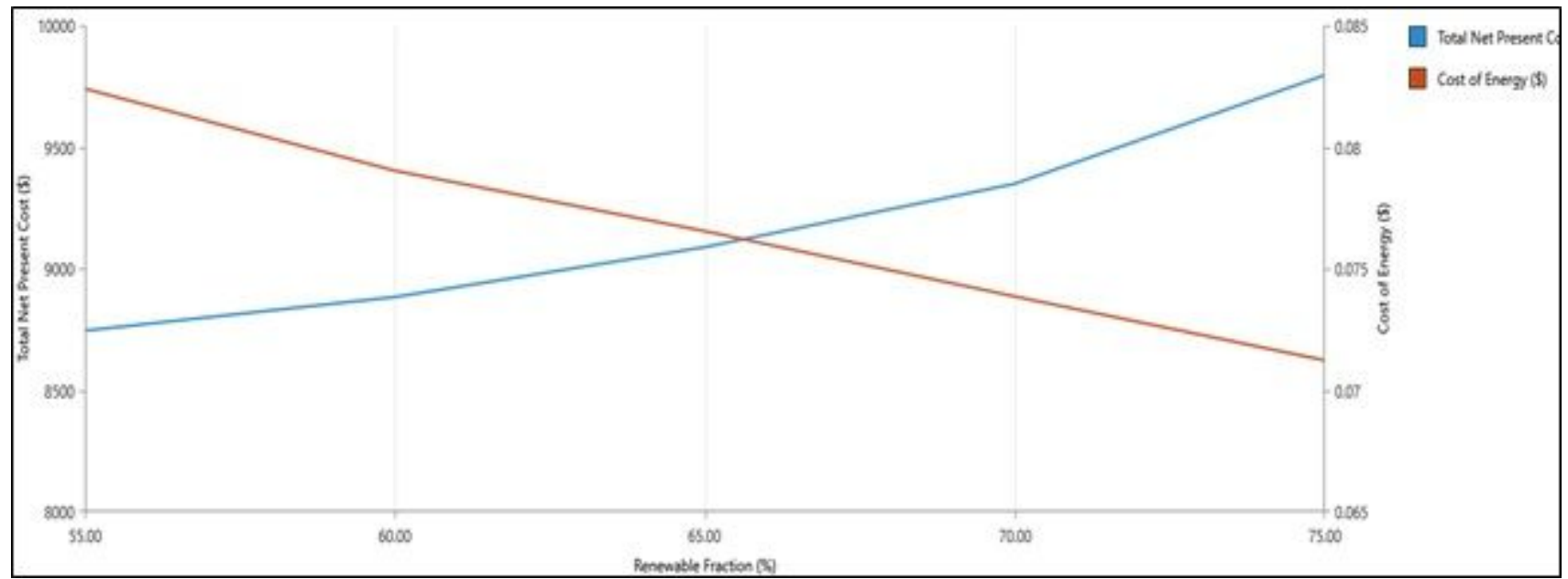


Figure 11

Cost of Energy vs. Renewable Fraction Percentage of PV On-Grid Optimum Water Pumping System

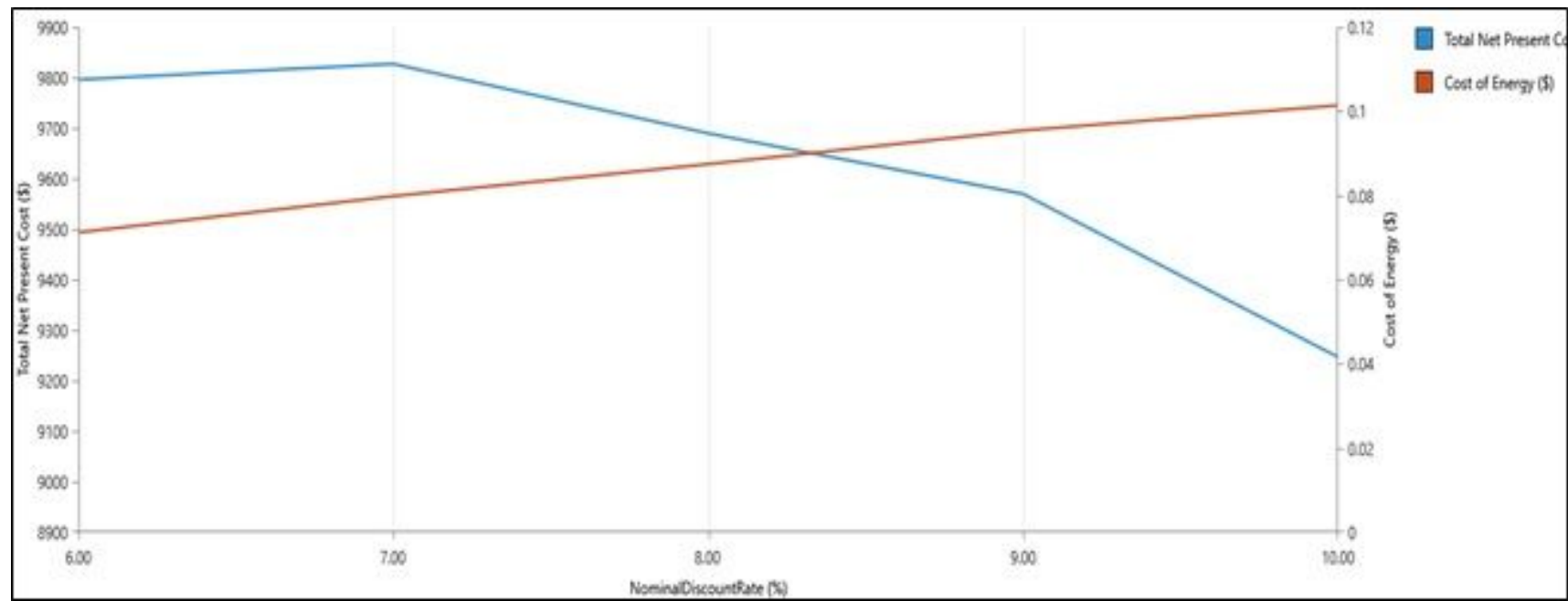

Figure 12

Net Present Cost vs. Discount Rate Percentage of PV On-Grid Optimum Water Pumping System

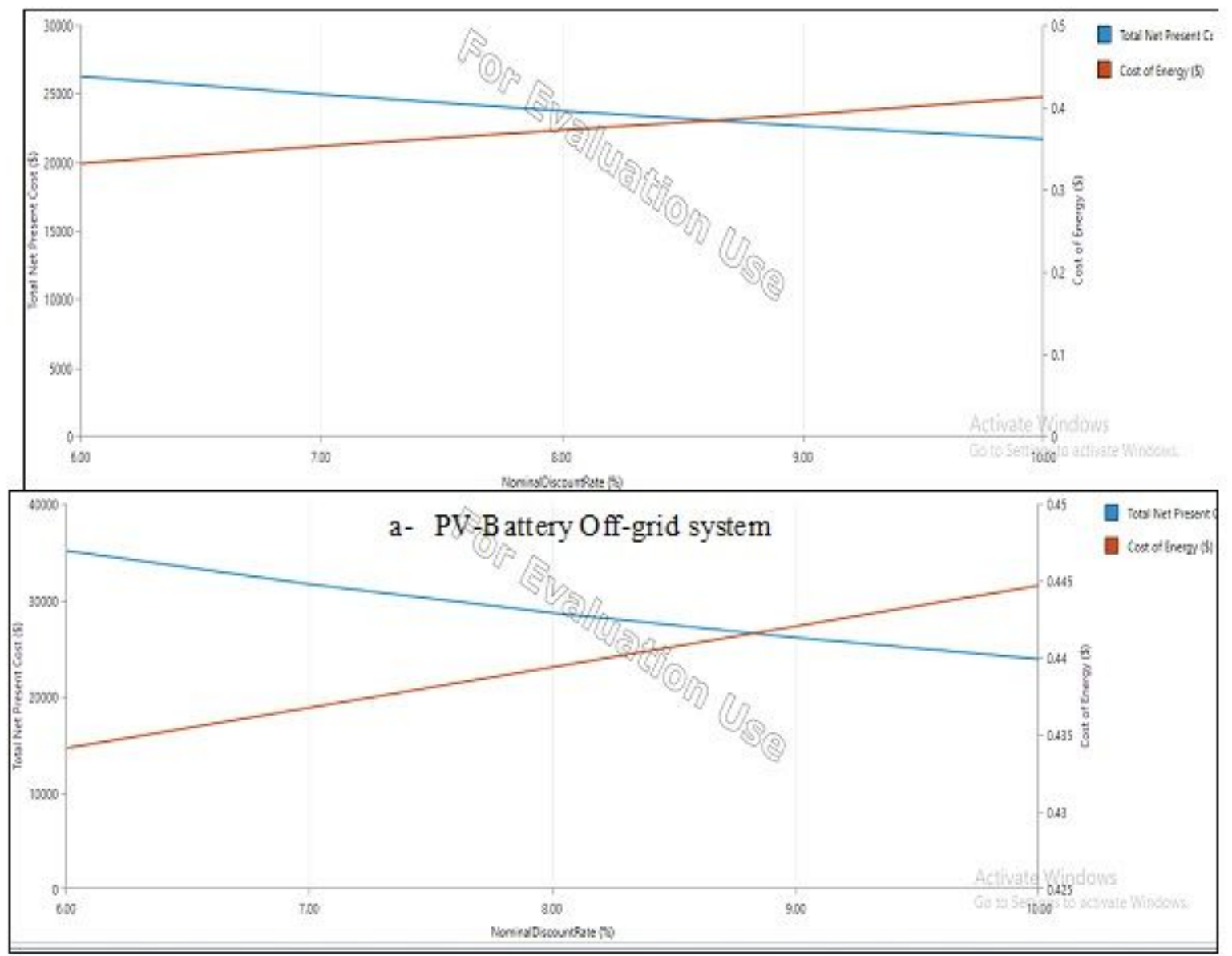

b- Diese1 System

Figure 13 
NPC \& COE vs. Discount Rate Percentage of PV-Battery/Diesel Water Pumping System 